\title{
Current concepts in clinical radiation oncology
}

\author{
Michael Orth • Kirsten Lauber • Maximilian Niyazi - Anna A. Friedl • \\ Minglun Li · Cornelius Maihöfer · Lars Schüttrumpf • Anne Ernst • \\ Olivier M. Niemöller • Claus Belka
}

Received: 10 June 2013/Accepted: 5 October 2013/Published online: 20 October 2013

(C) The Author(s) 2013. This article is published with open access at Springerlink.com

\begin{abstract}
Based on its potent capacity to induce tumor cell death and to abrogate clonogenic survival, radiotherapy is a key part of multimodal cancer treatment approaches. Numerous clinical trials have documented the clear correlation between improved local control and increased overall survival. However, despite all progress, the efficacy of radiation-based treatment approaches is still limited by different technological, biological, and clinical constraints. In principle, the following major issues can be distinguished: (1) The intrinsic radiation resistance of several tumors is higher than that of the surrounding normal tissue, (2) the true patho-anatomical borders of tumors or areas at risk are not perfectly identifiable, (3) the treatment volume cannot be adjusted properly during a given treatment series, and (4) the individual heterogeneity in terms of tumor and normal tissue responses toward irradiation is immense. At present, research efforts in radiation oncology follow three major tracks, in order to address these limitations: (1) implementation of molecularly targeted agents and 'omics'-based screening and stratification procedures, (2) improvement of treatment planning, imaging, and accuracy of dose application, and (3) clinical implementation of other types of radiation, including protons and heavy ions. Several of these strategies have already revealed promising
\end{abstract}

M. Orth · K. Lauber $\cdot$ M. Niyazi - A. A. Friedl · M. Li ·

C. Maihöfer · L. Schüttrumpf · A. Ernst .

O. M. Niemöller · C. Belka $(\bowtie)$

Department of Radiotherapy and Radiation Oncology, Ludwig-Maximilians-University of Munich, Munich, Germany

e-mail: claus.belka@med.uni-muenchen.de

Present Address:

O. M. Niemöller

Clinic for Radiation Oncology, St. Elisabeth Hospital

Ravensburg, Ravensburg, Germany improvements with regard to clinical outcome. Nevertheless, many open questions remain with individualization of treatment approaches being a key problem. In the present review, the current status of radiation-based cancer treatment with particular focus on novel aspects and developments that will influence the field of radiation oncology in the near future is summarized and discussed.

Keywords Radiotherapy · IMRT/IGRT $\cdot$ Particle therapy · Targeted therapy $\cdot$ Biomarkers .

Personalized medicine

\section{Introduction}

Cancer is the second most frequent cause of death within developed countries being responsible for 200-400 deaths per 100,000 people each year. The incidence of cancer is closely related to age, indicating that the probability of malignant transformation increases with life span. Additionally, cancer can evolve due to risk factors, such as cancer-causing lifestyle habits (e.g., cigarette smoking), genetic predisposition, and viral infections.

Radiotherapy, the clinical application of ionizing radiation, is one crucial treatment option in modern cancer therapy apart from surgery and systemic therapy as being corroborated by the fact that more than $60 \%$ of all cancer patients receive radiotherapy today. Radiotherapy can be used in various treatment settings ranging from definitive strategies to multimodal settings, e.g., in adjuvant and in neoadjuvant settings, with or without concomitant chemotherapy. The efficacy of radiotherapy has been proven in multiple randomized trials and has been described in metaanalyses that included multiple cancer types. Radiotherapy can significantly prolong patient survival and improve the 
local control rates of tumors. Furthermore, radiotherapy can help to avoid surgical amputation and to yield better cosmesis, and it can be used in palliative settings (Ringborg et al. 2003; Delaney et al. 2005).

For the treatment of head and neck cancer, radiotherapy may be used postoperatively, e.g., for patients with specific risk factors (Bernier et al. 2004; Cooper et al. 2004), but it has also been proven to be effective as primary definitive treatment strategy-particularly when being combined with concomitant chemotherapy (Pignon et al. 2009). In case of lung cancer, radiotherapy can be applied stereotactically for the treatment of early forms of bronchial carcinoma achieving high rates in local control (Guckenberger et al. 2009; Timmerman et al. 2010), and for advanced stages, it can be used in a neoadjuvant, adjuvant, or definitive manner as well as for palliation, respectively (Auperin et al. 2010; Albain et al. 2009; Douillard et al. 2006). For breast cancer, it was shown that breast-conserving surgery in combination with adjuvant radiotherapy results in survival rates that are equal to mastectomy (Fisher et al. 2002) and that omitting adjuvant radiotherapy causes a decrease by $4 \%$ in patient survival (Darby et al. 2011). Finally, in case of prostate cancer, radiotherapy with or without combined hormone therapy reveals comparable cure rates as surgical treatment efforts (Bolla et al. 2002), albeit randomized trials are missing. Taken together, all these findings demonstrate the importance of radiotherapy as one of today's crucial cancer treatment strategies, and the evidence for its effectiveness is still expanding.

\section{Technical improvements in precision of radiotherapy}

Since ionizing radiation is extremely effective in killing any kind of eukaryotic cell, a relevant therapeutic gain is only obtained when several prerequisites are met: adequate fractionation, optimal target delineation, radiation planning, image guidance, and toxicity diversification (radiochemotherapy). In recent years, intensity-modulated radiotherapy (IMRT) and image-guided radiotherapy (IGRT) comprise the most important technological advances (Fig. 1).

Intensity-modulated radiotherapy (IMRT) and image-guided radiotherapy (IGRT)

In principle, all radiation techniques that employ a nonhomogenous photon fluence over a given radiation field can be considered as "intensity modulated." In a more narrow sense, IMRT describes the sequential accumulation of multiple radiation fields resulting in a non-homogenous photon fluence from different gantry angles (Glatstein 2002). Currently, several variations in the IMRT principle are being used to achieve highly conformal radiation distributions: Classical IMRT, volumetric-modulated arc therapy (VMAT), Rapid Arc ${ }^{\circledR}$, Tomotherapy, and Cyberknife are different technological/vendor-specific solutions that are used to achieve optimal dose distributions while sparing normal tissues in an optimal fashion. To date, it has been proven that the use of IMRT achieves better conformity of the high-dose region to the target volume when compared to 3D conformal approaches, especially for complex treatment situations (Bortfeld 1999), in which adjacent organs at risk might compromise full coverage of the target volume (Mok et al. 2011).

Up to now, many trials have been performed documenting the feasibility of increased target doses with reduced toxicity using IMRT. Probably, the best examples are sparing of the parotid gland in head and neck cancer (Hey et al. 2011) and sparing of the rectum and the bladder while concomitantly increasing the target dose in prostate
Fig. 1 Improvements in clinical radiotherapy with decisive impact in recent years

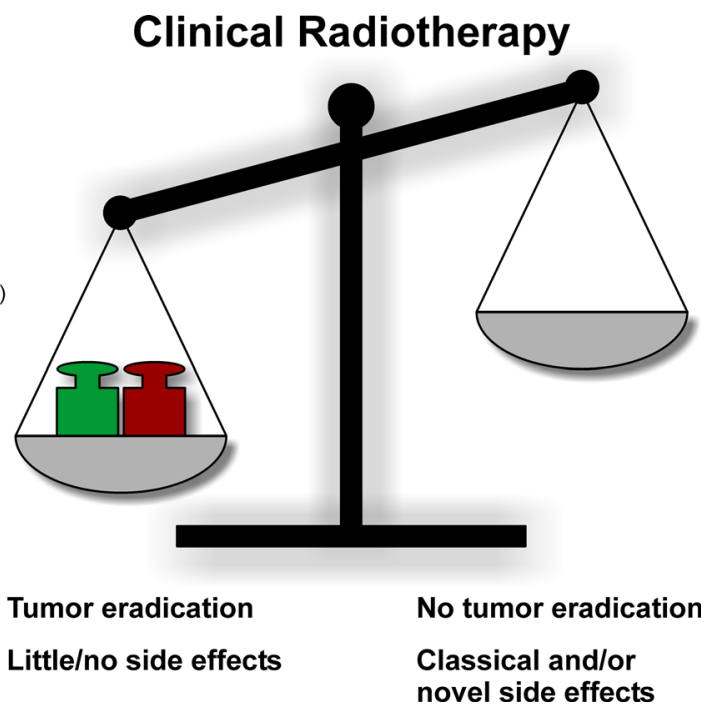


cancer (Takeda et al. 2012). However, randomized data that compare IMRT with classical 3D conformal radiotherapy are rare (Gupta et al. 2012). This is clearly related to the fact that it is difficult to set up a randomized trial whenever obvious differences in high-dose distributions are visible already after radiation plan comparison. In the meantime, more advanced rotational IMRT techniques such as VMAT and RapidArc ${ }^{\circledR}$ have entered clinical practice and allow for even faster application of prescribed doses. However, the clinical benefits of these techniques need to be further investigated (Jiang et al. 2011; Wiezorek et al. 2011; Foroudi et al. 2012; Fogarty et al. 2011). At present, the development strategies in the field of IMRT and related techniques basically aim at further improving the underlying planning and optimization algorithms as well as the technology of the LINACs in use. However, several open issues are not yet fully solved: (1) dose optimization in case of non-homogenous dose distributions, (2) toxicity prediction in case of non-homogenous doses to organs at risk, (3) reproducibility and verification of treatments with strongly increasing degrees of freedom (rotation, rotation speed, dose rate, field shape, etc.), and (4) mechanical stability and reliability of all components in use. Therefore, one focus of research is the development of planning algorithms, including tools for biological optimization and improved dose calculation (Monte Carlo calculations or similar). In addition, the technology providers aim at developing LINACs that are more and more "ab initio" designed for the implementation of the technologies mentioned above. In parallel, with increasing precision of radiation planning and dose application, the need for better target acquisition raises strongly. The term "target acquisition" covers merely all aspects of patient positioning, patient movement, internal organ movement between fractions, and internal organ motion within a fraction. In this regard, many different visualization tools are in use or in clinical testing. IGRT tools range from classical electronic portal imaging devices (EPIDs) (Njeh et al. 2012) and MV and kV cone-beam CTs (Foster et al. 2012) to complex 3D ultrasound (Chadha et al. 2011) and surface scanners (Pallotta et al. 2012). The wide use of these imaging devices will change the classical target volume approaches considerably. To date, the gross target volume (GTV) -> clinical target volume (CTV) -> planning target volume (PTV) concept is rather static using predefined safety margins in order to compensate for any kind of movement. Replacing this paradigm by daily "online" controls allows for smaller margins, which only reflect biological uncertainties.

In a wider sense, the term "IGRT" describes the use of advanced imaging technology, in order to optimally define target volume sites and organs at risk. At present, several imaging modalities have entered clinical practice in radiation oncology. 18F-Fluorodeoxyglucose (FDG)-based positron emission tomography (PET)-CT is frequently helpful during target volume definition. Highly specific PET markers such as tetraazacyclo-dodecane-tetraacetic acid (DOTA)-octreotide (DOTATOC) and DOTA-octreotate (DOTATATE) strongly improve the definition of the target volume for meningioma (Gehler et al. 2009). Even less specific markers (e.g., 18F-fluoroethyltyrosine (FET)PET) may strongly influence radiation treatment planning for glioma patients. In this regard, several groups have shown that FET-PET alters treatment volumes in roughly $50 \%$ of the cases (Niyazi et al. 2012b). Nevertheless, many issues are currently unsolved: Specificity and sensitivity of merely all tracers are not high enough to allow for automated segmentation of the target volumes. Besides PET-CT, other means of advanced imaging also influence target volume delineation in radiation oncology. At present, the definition of the adjuvant lymphatic drainage region follows empiric and pragmatic rules (Vorwerk and Hess 2011) rather than individual patient-oriented considerations. For the prostate, several groups have analyzed the feasibility of SPECT-based sentinel analysis to define individual lymphatic regions at risk (Vees et al. 2012; Ganswindt et al. 2007). Similarly, more specific MRI tracers would be of key importance for improved target volume definition in various disease sites (Weidner et al. 2011). Thus, it is clear that the combination of improved imaging, both for delineation of the target volume and during treatment, will play a key role in future radiation oncology (Xing et al. 2006). In this regard, the use of IGRT results already today in less acute toxicity during radiotherapy, e.g. in case of prostate cancer (Gill et al. 2011; Crehange et al. 2012).

\section{Protons and heavy ions}

Several recent developments like IMRT allow for the reduction in the dose exposed to normal tissue while keeping the prescribed dose on the tumor volume. However, these methods come at the cost of increasing the volume of normal tissues receiving low or moderate doses, and it has been assumed that this may increase the risk of radiation-induced secondary cancers (Hall 2009) although clinical or epidemiological data are not available yet. Charged particles such as protons or heavy ions deliver the highest dose near the end of their range, in the so-called Bragg peak. This allows for extremely steep dose gradients distal to the Bragg peak and thus for superior sparing of organs at risk in the vicinity of the target. Because there is, apart from a dose that is due to secondary particles or fragments, no exit dose and because entrance doses are lower than in the case of photons, this allows for an overall reduction in the integral dose outside the planned target 
area, which is expected to significantly reduce the risk of radiogenic secondary malignancies in long-term cancer survivors (Fontenot et al. 2010; Newhauser and Durante 2011). So far, no long-term epidemiological studies on the incidence of secondary cancer cases following a proton- or a heavy ion-based cancer treatment are available, and given the latency period associated with radiation-induced tumors, these studies will also not be available in nearer future. The knowledge of radiation-induced tumorigenesis and the many parameters involved (e.g., radiation dose and quality, fractionation, age at exposure, genetic susceptibility) is limited, and therefore, risk estimations are difficult to perform. For example, passive beam scattering, which has been the predominant method for increasing the size of the proton pencil beam generated by the accelerator up to now, produces secondary neutrons with a broad range of energies for some of which the relative biological effectiveness (RBE) is poorly characterized (Hall 2009), and therefore, the impact of these neutrons on secondary tumor risk is difficult to estimate. It should be noted that part of secondary neutron production is reduced in particle therapy setups using active beam scanning (Clasie et al. 2010).

So far, only a few clinical studies have been performed on the efficacy and acute side effects of proton and ion therapy, and only very few of them have directly compared the outcome of particle therapy and conventional radiotherapy. Brada et al. (2009) gave a detailed overview on the clinical impact of proton therapy based on a search within published, peer-reviewed literature. They identified 52 studies of proton therapy fulfilling their quality criteria (at least 20 patients with a follow-up period of at least 2 years), encompassing data of in total 13,736 patients (Brada et al. 2009). Of these patients, 10,328 received treatments for ocular tumors and 1,642 were treated for prostate tumors and 880 for tumors of the central nervous system (CNS). Other tumor entities such as head and neck tumors, gastrointestinal tumors, lung cancer, and sarcomas were subjects of two to five studies each, encompassing between 97 and 375 patients per tumor site. This number must be compared to more than 60,000 patients who had undergone a proton-based cancer therapy by the end of 2008 (http://ptcog.web.psi.ch/Archive/Patientstatisticsupdate02Mar2009.pdf). Brada and coauthors concluded that the evaluated literature lacks any evidence demonstrating a clear benefit of proton-based therapy if compared to the best available conventional therapies with respect to tumor control, patient survival, and side effects. Others studies came to similar conclusions, even with respect to pediatric tumors (Bouyon-Monteau et al. 2010), prostate cancer (Kagan and Schulz 2010), lung cancer (Liao et al. 2011), head and neck cancers (Ramaekers et al. 2011), and tumors of the skull base treated by radiosurgery (Amichetti et al. 2012). A recent study even showed higher rates of gastrointestinal side effects after a proton-based therapy if compared to conventional IMRT of prostate cancer (Sheets et al. 2012), but the methodology applied in this study is under debate (Deville et al. 2012; Mendenhall et al. 2012; Jacobs et al. 2012). Clearly, the absence of evidence is not evidence of absence of a superior efficacy or tolerance of proton therapy, but nevertheless, these analyses clearly stress the requirement of more clinical studies assessing the clinical impact of proton-based cancer therapy.

The better the conformity, the higher are the requirements for setup reproducibility, accuracy in patient immobilization, and consideration of changes in the patient's anatomy, such as the motion of organs (e.g., due to filling of the bladder or the rectum), or treatmentinduced alterations, e.g., tumor shrinkage. This holds for a highly conformal therapy with both photons and protons. The impact of intrafraction mobility, which is affected by the duration of the treatment, may be of special importance in case of an active proton beam scanning, because this method takes considerably more time than passive scattering or photon irradiation. Importantly, in the case of protons, an additional level of complexity comes into play since absorption and scattering of protons largely depend on the material traversed so that the range and the lateral penumbra are affected by the inhomogeneity of the tissue. Uncertainty in estimating the particle range will automatically translate into dose uncertainties. In spite of demands for state-of-the-art imaging, image guidance, and dose verification, several authors raised concerns about the lack of optimal technologies at proton therapy facilities (Merchant 2009; Schippers and Lomax 2011). As already pointed out by Goitein in 2008, the possibility for treatment errors is much greater in case of protons than with photons and therefore, proton therapy has to be used exclusively in a highly controlled fashion (Goitein 2008).

Carbon ions are less affected by energy straggling and scattering as compared to protons, and therefore, the precision of the dose deposition achievable is even greater than in the case of protons. However, due to fragmentation processes, a dose tail is always present distally from the Bragg peak, which must be considered in treatment planning. These fragmentation processes come, however, also with an advantage, namely the generation of positron emitters that allow for in situ beam monitoring (Weber and Kraft 2009). One major potential of carbon ions lies in the fact that they can confer a significant higher RBE than photons within their Bragg peak region, and this not only means that the physical dose there is highest, but also the biological effect achievable per dose unit. The expenses for carbon-ion-based radiotherapy units are, however, even greater than for proton facilities, and only few facilities have been available in the past. Since 2009, 
the carbon ion radiotherapy unit at the Heidelberg Ion Therapy (HIT) center which uses active beam scanning is operating, and initial data on clinical experiences become available now (Combs et al. 2010b). At HIT, all patients are treated within clinical trials (Combs et al. 2010a, c; Jensen et al. 2011a, b), and recently, randomized phase III trials have been initiated to compare proton- and carbonion-based therapies for the treatment of chondrosarcomas and chordomas (Nikoghosyan et al. 2010a, b). Due to their higher RBE, the treatment with carbon ions might be more effective for the cure of radioresistant tumors. A recent meta-analysis performed in different head and neck cancers compared the efficacies of photons, protons, and carbon ions (Ramaekers et al. 2011) but, so far, only revealed a survival benefit for mucosal malignant melanomas after a carbon-ion-based therapy, which might reflect a high grade of resistance of this particular tumor entity toward irradiation in general. Other work suggests that due to the reduced volume of normal tissue that is exposed to modest doses, particle therapy may confer advantages in treatments using concurrent drug administration (Nystrom 2010). In a modeling study, Vogelius et al. (2011) estimated the pneumonitis risk after a treatment with photons or protons either in combination with or in the absence of chemotherapy and came to the conclusion that proton therapy could potentially minimize the risk by reducing the volume that is exposed to lower doses (Vogelius et al. 2011). Given the increasing role of multimodality treatment approaches, further investigations into the relative merit of particle therapy in these settings are clearly needed.

The controversial discussion on the necessity of clinical studies of particle therapy is, in part, fuelled by the high costs of this treatment if compared to established photon therapy. One part of such elevated costs is due to the size of the synchrotrons or cyclotrons used, and there are several developments that aim for provision of smaller accelerators (Schippers and Lomax 2011). One putative solution could be the acceleration of protons and also of heavier ions by laser acceleration (Tajima 2010). Although current technologies are far from clinical application, some research groups already started to address the question of whether the RBE of laser-driven particles may differ from that of conventionally accelerated particles, thereby focusing on the ultrashort pulsing process by which these particles are generated as well as on the ultra-high dose rates associated with it (Rigaud et al. 2010; Yogo et al. 2009; Kraft et al. 2010; Bin et al. 2012). By simulating the pulsed radiation conditions expected in therapy settings using laser-accelerated protons of a pulsed proton beam at the Munich ion microbeam SNAKE (Dollinger et al. 2009), an extensive series of experiments with various endpoints in cell monolayers,
3D tissue culture models, and tumor xenografts were conducted. However, no significant differences between a dose of a few Gy that was given in about 1 ns (the dose rate expected after laser acceleration) and the same dose given in about $100 \mathrm{~ms}$ (the dose rate at conventional irradiation settings) could be observed in these experiments (Schmid et al. 2009, 2010; Auer et al. 2011; Greubel et al. 2011; Zlobinskaya et al. 2012).

\section{Biological improvements of radiotherapy}

During the last decades, significant improvements have been made: A special focus has been placed on the development of advanced planning procedures (van Herk 2004), the physical accuracy of dose application (Bucci et al. 2005) and combined modality treatment approaches in terms of radiochemotherapy (Al-Sarraf et al. 1998) (Fig. 1). However, dose escalation studies revealed that the combination of radiotherapy with classical chemotherapy has reached some kind of dead end (Budach et al. 2006). At this point, the combination of radiotherapy with molecularly designed agents specifically targeting the hallmarks of cancer has revealed significant improvements in clinical outcomes when compared to each treatment strategy alone (Begg et al. 2011). However, the effective integration of molecularly targeted drugs requires a detailed patient stratification, since only those patients with relevant signal aberrations will benefit. Furthermore, it has to be noted that stratification is urgently needed in order to avoid side effects induced by the addition of such targeted drugs (Niyazi et al. 2011b). In the following paragraphs, the key biological targets for specifically improved radiotherapy will be introduced.

\section{The hallmarks of cancer}

The emergence of cancer, in general, is due to failures within mechanisms or pathways that control the growth, the proliferation, and/or the death of cells in response to extracellular or intracellular signals. Deregulations within these mechanisms can commit cells to sustained proliferation, replicative immortality, evasion of growth suppression, and resistance to cell death-attributes commonly shared by malignantly transformed cells (Hanahan and Weinberg 2000). However, the transition from a single transformed cell toward the formation of a solid tumor requires additional features, such as the capacity to instigate the formation of blood vessels (angiogenesis and/or neovascularization), mechanisms to evade immune responses, as well as an increased potential to invade other tissues (metastasis) (Hanahan and Weinberg 2011). 


\section{Sustained proliferation and replicative immortality}

The growth as well as the proliferation of cells is orchestrated by a class of signaling molecules called mitogens. While in non-transformed cells, the synthesis and the release of mitogens are tightly controlled, these processes are often deregulated in cancer cells. Such deregulation can be due to the acquisition of genetic mutations (for instance due to exposure to tumor-initiating chemicals and/or ionizing radiation) or to the experience of growth-supporting signals, such as tumor-promoting chemicals and chronic inflammation. Two of the best-characterized mitogens are the platelet-derived growth factor (PDGF) and the epidermal growth factor (EGF). The binding of these ligands to their respective receptors, PDGFR and epidermal growth factor receptor (EGFR), activates sophisticated signaling pathways, including the mitogen-activated kinase (MAP kinase) pathway, thereby stimulating both the growth and the proliferation of cells (Seger and Krebs 1995). Mutations within the genes that encode for such mitogens/ receptors can render the corresponding gene products in a state of constitutive activation culminating in uncontrolled growth and/or proliferation of cells. In this regard, the gene encoding the small GTPase K-Ras provides a prototypical example as activating mutations of K-Ras are found in diverse cancer entities, e.g., in more than $40 \%$ of all colorectal cancers (Karapetis et al. 2008). Similar examples can be found in other mitogenic signaling pathways, including the phospho-inositide-3-kinase (PI3 K)/AKT kinase and the insulin-like growth factor (IGF) pathway (Chang et al. 2003; Fresno Vara et al. 2004; Samani et al. 2007; Frasca et al. 2008).

With regard to their impact on the outcome of radiotherapy, both overexpression and mutation of EGFR were shown to correlate with increased resistance of tumors to irradiation and poor clinical prognosis (Lammering et al. 2003, 2004; Giralt et al. 2005; Milas et al. 2004). Furthermore, ligand-independent activation of EGFR in response to irradiation and the subsequent activation of its downstream signaling cascades apparently contribute to radioresistance (Iyer et al. 2004; Gupta et al. 2001; Toulany et al. 2005). Therefore, multiple strategies have been developed in order to interfere with EGFR function as being discussed in more detail later on.

A key step in malignant transformation is the acquirement of basically limitless replicative potential. After a certain number of division cycles, a normal cell exits the cell cycle and transits into senescence, a stage of metabolic activity devoid of further proliferation (Campisi and d'Adda di Fagagna 2007). The induction of senescence requires a group of proteins encoded by genes that are known as tumor-suppressor genes (e.g., p53, pRB). These genes negatively regulate the growth and/or the proliferation of cells, and hence, mutations that render their products inactive can support both immortalization and unrestrained proliferation. Another prerequisite for replicative immortality is the cell's capacity to protect its telomeres (Blasco 2005). Since expression of telomerase is almost absent in non-immortalized cells, their replicative potential is greatly limited by successive telomere shortening. In immortalized cells (including cancer cells), to the contrary, expression of telomerase is reinitiated, thereby counteracting the erosion of telomeres and, in consequence, the induction of senescence or apoptosis. Additionally, expression of telomerase and telomere length have been reported to contribute to radioresistance of tumor cells (Genesca et al. 2006).

\section{Evasion of growth suppression and resistance to cell death}

Aside from extensive proliferation, the formation of solid tumors necessitates the cellular capacity for evading growth-suppressive signals, which mostly depend on tumor-suppressor proteins, such as p53 or the members of the retinoblastoma protein family. These proteins interfere with cell proliferation in response to growth-inhibiting signals and/or intracellular disorders including DNA damage either by blocking the expression of genes required for cell cycle progression or by initiating the expression of cell cycle-inhibiting genes such as $\mathrm{p} 16^{\mathrm{INK} 4 \mathrm{a}}$ and $\mathrm{p} 21^{\mathrm{WAF} 1}$ (Sherr and Roberts 1999). Alternatively, tumor-suppressor proteins (in particular p53) can also stimulate the induction of a programmed form of cell death called apoptosis, e.g., in response to DNA damage, explaining p53's pivotal role in determination of tumor radiosensitivity (Gudkov and Komarova 2003). In this context, p53 induces the expression of several pro-apoptotic proteins (e.g., PUMA) and thereby facilitates the induction of apoptosis. However, many cancer cells circumvent apoptosis, e.g., by inactivating p53, by down-regulating pro-apoptotic genes, or by up-regulating antiapoptotic genes.

\section{Angiogenesis and neovascularization}

Since the formation of solid tumors demands for a continuous nutrient and oxygen supply, tumor cells must acquire the capacity to stimulate vascularization involving de novo formation of blood vessels (vasculogenesis) as well as sprouting of newly formed vessels from preexisting ones (angiogenesis). In adults, angiogenesis and vasculogenesis are tightly limited to certain physiological processes, such as wound healing. However, during tumor progression, angiogenesis is reinitiated (Bergers and Benjamin 2003). To this end, tumor cells secrete pro-angiogenic factors, such as the vascular endothelial growth factor (VEGF) that, upon binding to their respective 
receptors (VEGFR), stimulate the proliferation of endothelial cells resulting in increased vessel formation and tumor infiltration. VEGF expression in tumor cells is facilitated by certain oncogene products, including c-Myc or H-Ras, whereas non-transformed cells express VEGF almost exclusively under hypoxic conditions (Baudino et al. 2002; Chin et al. 1999). The degree of vascularization plays an important role in regard to the tumor's responsiveness to ionizing radiation. As the induction of DNA damage is supported by the presence of oxygen, increased hypoxia limits the efficacy of radiotherapy. Consequently, intense efforts are spent in order to increase tumor oxygenation and to improve the therapeutic effect of exposure to ionizing radiation (Wachsberger et al. 2003).

\section{Evasion of immune responses}

Another barrier limiting the formation and the progression of tumors is the immune system. This becomes clear by the fact that immunocompromised mice, e.g., mice that are deficient in $\mathrm{CD}^{+} \mathrm{T}$ lymphocytes or natural killer (NK) cells, show a significant higher susceptibility to cancer than those that are immunocompetent (Schreiber et al. 2011). Consequently, it is no wonder that tumor cells acquire multiple mechanisms to evade immune responses, such as elimination and/or aberration of tumor antigens/MHC class I molecules, secretion of immunosuppressive cytokines such as transforming growth factor $\beta$ (TGF- $\beta$ ) and interleukins, recruitment of immunosuppressive immune cells (e.g., $\mathrm{CD} 4^{+} \mathrm{CD} 25^{+}$regulatory $\mathrm{T}$ cells and myeloid-derived suppressor cells), or expression of indolamine-2,3-dioxygenase (IDO) (Kaufman and Disis 2004; Munn and Mellor 2007; Garcia-Lora et al. 2003). Several lines of evidence support the notion that the immune system plays a pivotal role in tumor regression in response to radiotherapy (Lauber et al. 2012). This is of particular interest, since the induction of an antitumor immune response might not only be helpful for the elimination of the primary tumor within the irradiation field, but also for out-of-field metastases (Frey et al. 2012).

\section{Tissue invasion and metastasis}

Aside from their capacity to form primary tumors, some malignantly transformed cells also acquire the capacity to infiltrate neighboring tissues or even penetrate lymphatic and/or blood vessels, giving rise to several kinds of secondary tumors or metastases. Usually, metastasis starts with the detachment of tumor cells from the primary tumor site facilitated by the repression of factors that mediate cellular adhesion, such as E-cadherin, and by secretion of enzymes that degrade extracellular matrices (ECMs), thus liberating tumor cells from their surroundings (Valastyan and Weinberg 2011). These processes depend on the activation of a conserved cellular program termed the epithelial-mesenchymal transition (EMT), which regulates the formation of the mesoderm and the neural tube during embryonic development (Thiery et al. 2009). For several tumor entities, glioblastomas in particular, it was shown that irradiation increases their invasive potential and thus might even accelerate local dissemination and development of distant metastasis (Qian et al. 2002; Cordes et al. 2003; Wild-Bode et al. 2001; Camphausen et al. 2001).

Mechanisms of cell death

Radiotherapy is an important treatment modality in clinical cancer therapy because of its great potential to kill malignant cells and to abrogate clonogenic survival. Directly or indirectly, ionizing radiation induces different types of genome damage, including DNA double-strand breaks (DSBs), bulky lesions, and others, thereby activating a highly sophisticated signaling network termed the DNA damage response (DDR) culminating in transient or permanent cell cycle arrest and/or cell death, respectively (Fig. 2).

\section{DNA damage response (DDR)}

The DDR mediates cellular responses to various kinds of DNA damage, a cell has to cope with. The DDR is regulated by two conserved protein kinases called Ataxia telangiectasia mutated (ATM) and Ataxia telangiectasia and Rad3 related (ATR) (Smith et al. 2010). ATM is recruited to DSBs by the Mre11-Rad50-Nbs1 (MRN) complex where it phosphorylates the histone $\mathrm{H} 2$ variant $\mathrm{H} 2 \mathrm{AX}$, thereby creating a recruitment platform for other DDR factors (Shiloh 2006). In parallel, ATM mediates resection of the broken DNA strand(s), and the resulting ssDNA repair intermediates specifically activate ATR kinase (Hurley and Bunz 2007). By phosphorylation of two respective downstream kinases termed CHK1 and CHK2, ATR and ATM trigger a multitude of signaling pathways, thereby initiating both a transient arrest within cell cycle progression and DNA damage repair. However, in case of excessive DNA damage, ATM/ATR can also induce cellular senescence and/or cell death (Jackson and Bartek 2009).

The major target of the ATM/ATR cascade in terms of arresting the cell cycle or committing the cell to cell death is the tumor-suppressor protein p53. In the absence of DNA damage, the overall levels of p53 within the cell are maintained rather low because of the association of p53 with the ubiquitin ligase MDM2 (HDM2 in human). MDM2 continuously ubiquitylates p53, thereby targeting p53 for proteasomal degradation. Yet, in the context of the DDR, p53 is phosphorylated by kinases of the ATM/ATR 
Fig. 2 Mechanisms of cell death triggered by ionizing radiation

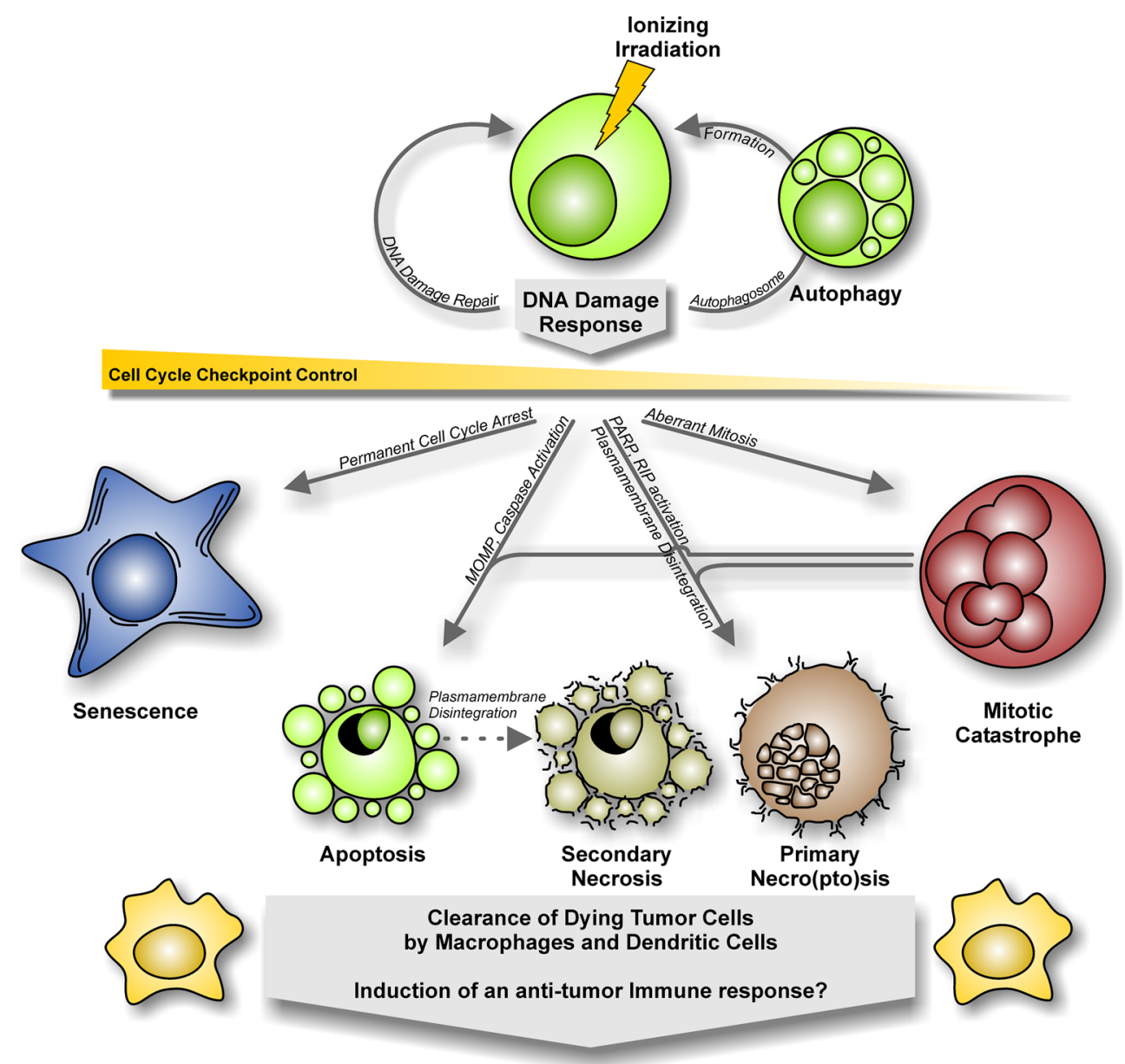

Reduced Tumor Burden cascade leading to its dissociation from MDM2 and thus to stabilization of p53 (Meek 2009). Once being stabilized, the transcription factor p53 crucially regulates cell cycle arrest, DNA damage repair, and the induction of cell death or senescence by inducing or repressing the expression of several target genes that encode for factors involved in these processes (Sengupta and Harris 2005).

\section{Apoptosis}

Apoptosis is a form of programmed cell death, which is characterized by chromatin condensation/fragmentation, cell shrinkage, and blebbing of cell membranes. In response to irradiation, apoptosis is predominantly observed in cells of the hematopoietic system. Radiationdependent induction of apoptosis mainly relies on the intrinsic death pathway (Rudner 2001), in which cytochrome $\mathrm{c}$ is released into the cytosol by permeabilization of the outer mitochondrial membrane. This, in turn, stimulates the formation of the apoptosome and subsequent activation of the caspase cascade. The cleavage of multiple caspase substrates within the cell finally results in chromatin fragmentation, organelle destruction, and cellular disintegration (Taylor et al. 2008). The process of mitochondrial permeabilization is essentially controlled by pro- and antiapoptotic members of the B-cell lymphoma-2 (Bcl-2) family, which regulate the channel-forming activity of the family members BAX and BAK (Chipuk et al. 2010; Youle and Strasser 2008). Protein p53 can modulate this equilibrium in response to DNA damage by inducing the expression of pro-apoptotic Bcl-2 family members, such as PUMA, NOXA, and BAX itself (Sengupta and Harris 2005).

Stimulation of apoptosis via the extrinsic death pathway, on the contrary, depends on the binding of death ligands (e.g., CD95L, TRAIL) to their respective cell surface receptors (Debatin and Krammer 2004). Subsequent death receptor clustering triggers the activation of the caspase cascade in this pathway. Although the expression levels of several key regulators of the extrinsic pathway have been described to increase upon exposure to ionizing radiation (Belka et al. 1998; Haupt et al. 2003), the intrinsic pathway appears to be the dominant pathway of apoptosis induction in response to DNA damage (Rudner 2001). Additionally, 
it should be noted that cells deficient in p53 function can undergo radiation-induced apoptosis as well, indicating that alternative mechanisms such as p63-/p73-dependent expression of pro-apoptotic factors can compensate for the lack of p53 in these cases (Afshar et al. 2006; Wakatsuki et al. 2008).

\section{Necroptosis/Necrosis}

When activation of caspases is prevented, DNA damage can induce an alternate form of cell death termed necroptosis. Necroptosis depends on hyperactivation of the poly-ADP-ribose-polymerase (PARP), a protein involved in DNA excision repair, and subsequent activation of receptor-interacting protein (RIP) — kinases as a response to depletion of intracellular ATP. Necroptosis, once being triggered by a structure called the necrosome, is characterized by the appearance of reactive oxygen species (ROS), lipid peroxidation, failure in calcium homeostasis, organelle swelling, and plasma membrane rupture (Vandenabeele et al. 2010). It appears to be of special importance in cancer cells of epithelial origin which reveal a limited apoptosis induction capacity in response to ionizing radiation, and also when irradiation is applied in high doses or in combination with hyperthermia (Mantel et al. 2010; Schildkopf et al. 2010). Additionally, high doses of ionizing radiation can stimulate necrosis, an accidental, uncontrolled type of cell death, which is predominantly characterized by rupture of the plasma membrane and a resulting release of intracellular contents, including danger signals, which can potently alert the immune system.

\section{Mitotic catastrophe}

The term "mitotic catastrophe" describes a cellular condition, which results from aberrant cell cycle progression prior to mitotic entry or during cell division itself. Mitotic catastrophe is characterized by the formation of huge cells with multiple nuclei as well as hyperamplified centrosomes. It might constitute the predominant mechanism of radiation-dependent cell death in cells with defective cell cycle checkpoints (Eriksson and Stigbrand 2010). However, cells, which have undergone mitotic catastrophe, might survive for several days, transit into senescence, or die by apoptosis and/or necro(pto)sis due to their high degrees of aneuploidy.

\section{Cellular senescence}

Cellular senescence is a state of permanent cell cycle arrest, which can be instigated by DNA damage. Senescence induction requires function of certain cell cycle checkpoint components, such as p53 and the retinoblastoma protein $\mathrm{pRB}$, but it has also been observed in the absence of functional p53 (Nardella et al. 2011). Senescent cells are active in terms of metabolism, but do not show further cell cycle progression. Central features of senescent cells comprise a flattened morphology, an increase in granularity, the up-regulation of cyclin-dependent kinase inhibitors, and a positive staining for $\beta$-galactosidase (SA$\beta$-Gal). Furthermore, senescent cells have been reported to release factors that can support as well as inhibit malignant progression by influencing both the proliferation of neighboring cells and antitumor immune responses (Krtolica et al. 2001; Eriksson and Stigbrand 2010; Coppe et al. 2010).

\section{Autophagy}

Autophagy represents a cellular state that is currently being discussed as both a mechanism of cell death and cell survival (Apel et al. 2009). It is characterized by the sequestration of proteins and/or organelles within huge autophagic vesicles called autophagosomes. As fusion of these vesicles with lysosomes leads to the formation of autophagolysosomes and degradation of their content providing material for de novo synthesis and regeneration, it is rather unclear whether autophagy represents a mechanism of survival or cell death, respectively. Autophagy involves the activation of multiple protein kinases, including the class I phosphatidylinositol-3-kinases (PI3 K-I), stress kinases, and the mammalian target of rapamycin (mTOR) kinase, and it has been observed in response to exposure to ionizing radiation (Apel et al. 2008).

\section{Immunological consequences}

The induction of tumor cell death and the inhibition of clonogenic survival by the application of ionizing radiation are central elements of its therapeutic success. Yet, it is well accepted that mechanisms involving both the innate and the adaptive immune system contribute to tumor regression-particularly in the context of ablative radiotherapy, where irradiation is applied in high single doses of 10 Gy or more (Lauber et al. 2012). In this regard, local high-dose radiotherapy of transplanted mouse B16 melanoma has been reported to stimulate the generation of tumor antigen-specific, interferon- $\gamma$ (IFN- $\gamma$ )-producing $\mathrm{T}$ cells (Lugade et al. 2005). Moreover, ablative, but not fractionated, radiotherapy drastically enhanced $\mathrm{T}$ cell priming in tumor-draining lymph nodes, which was paralleled by a regression of the primary tumor as well as distant, out-of-field metastases in a $\mathrm{CD} 8^{+} \mathrm{T}$ cell-dependent manner (Lee et al. 2009). Mechanistically, these $\mathrm{T}$ cells apparently have been primed by dendritic cells (DCs), 
which carry ingested tumor material and cross-present it in the tumor-draining lymph nodes. A recent study showed that the intratumoral production of type I interferons (IFN$\alpha / \beta)$ in response to ablative radiotherapy is key in this scenario, since it enhances the cross-presenting capacity of tumor-infiltrating DCs (Burnette et al. 2011). This cascade of interferons, where IFN- $\alpha / \beta$ produced by $\mathrm{CD} 11 \mathrm{c}^{+}$cells (presumably DCs and macrophages) enhances the crosspriming activity of $\mathrm{CD} 8 \alpha^{+}$DCs thereby stimulating the generation of IFN- $\gamma$-producing $\mathrm{CD} 8^{+} \mathrm{T}$ cells and, finally, tumor rejection, is well known from the field of tumor immunoediting (Diamond et al. 2011; Fuertes et al. 2013). Here, IFN- $\alpha / \beta$ and IFN- $\gamma$ contribute on different levels to the reduction in tumor burden. Whereas IFN- $\alpha / \beta$ primarily exerts its effects on macrophages, DCs, and NK cells by facilitating their activation and maturation and by enhancing their capacity to induce adaptive immune responses (Dunn et al. 2006), IFN- $\gamma$ directly affects the tumor via inhibition of tumor cell proliferation, apoptosis induction, inhibition of angiogenesis, and an overall enhancement of tumor immunogenicity (Dunn et al. 2006; Lugade et al. 2008; Reits et al. 2006). Additionally, IFN- $\gamma$ contributes to the stimulation of an antitumor immune response since it is essentially involved in $T_{H} 1 / T_{C} 1$ cell responses and exerts similar effects as IFN- $\alpha / \beta$ in terms of innate immune cell activation and DC-mediated antigen cross-presentation (Dunn et al. 2006). This interferon cascade of innate and adaptive immune responses has only been described in case of ablative but not conventional, fractionated radiotherapy (Lee et al. 2009), and the question that needs to be addressed is why. One feasible explanation could be that ablative and fractionated radiotherapy trigger different tumor cell responses in terms of cell death and/or senescence induction with only high single-dose irradiation stimulating primary or secondary, postapoptotic secondary necro(pto)sis or senescence, respectively. The corresponding cellular releasates, a complex mixture of danger signals, and the senescenceassociated secretome are well known to be potent inducers of IFN- $\alpha / \beta$ and other pro-inflammatory cytokines and hence could initiate the IFN-cascade described above and the DC-mediated instigation of antitumor $\mathrm{T}$ cell responses (Coppe et al. 2010; Apetoh et al. 2007; Peter et al. 2010; Kuilman and Peeper 2009).

\section{Combination of radiotherapy (RTX) with targeted agents}

Despite the technical improvements in cancer radiotherapy in recent years, the combination of radiotherapy with classical chemotherapy has reached a dead end (Budach et al. 2006). Therefore, novel strategies encompassing the combination of conventional radiotherapy with agents that are specifically raised against key factors of malignant transformation have been designed and are currently being tested (Fig. 3). In the following paragraphs, current efforts

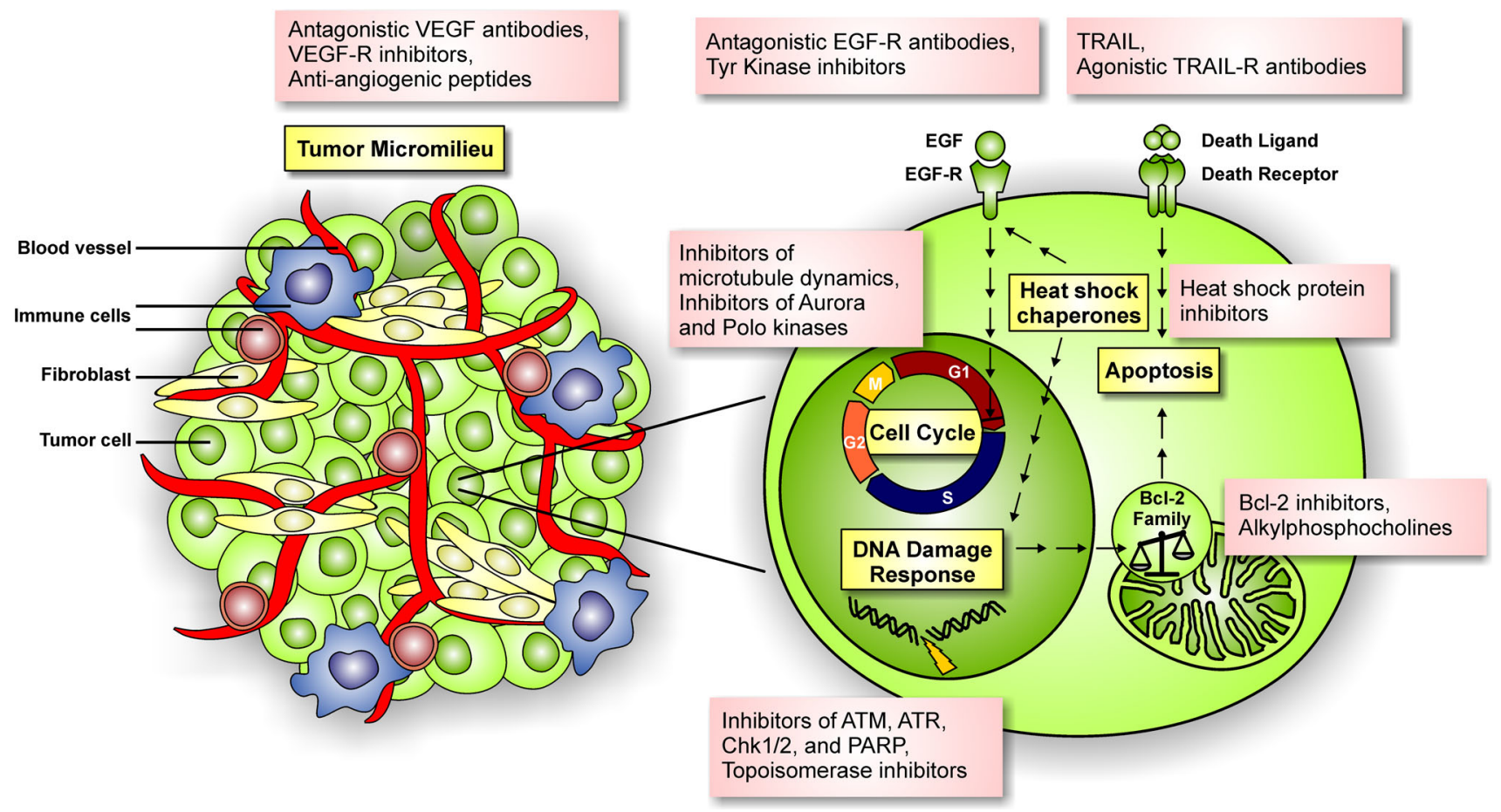

Fig. 3 Survey of valuable targets for combined modality approaches 
made in order to specifically target cellular compounds to improve the efficacy of clinical radiation oncology in the future are discussed.

\section{Combination of RTX with agents targeting the DDR}

As the cell-death-inducing potential of ionizing radiation is largely determined by the cells' capacity to cope with DNA damage, it is no wonder that both the expression and the functionality of DDR components have great impact on the efficacy of radiotherapy. This can be appreciated by the fact that the expression of DDR components within different tissues often correlates with the resistance or sensitivity of the respective tissue toward irradiation (Peters et al. 1982; Deacon et al. 1984). Therefore, targeted pharmaceutical agents, which interfere with proper function of the DDR, should be suitable to enhance the efficacy of conventional radiotherapy (Basu et al. 2012; Begg et al. 2011). Indeed, several studies revealed that interfering with ATM function (e.g., by using small-molecule inhibitors such as KU-55933) efficiently sensitizes human cancer cells to irradiation (Hickson et al. 2004; Cowell et al. 2005; Golding et al. 2009). Similar results have been reported for inhibitors of other DDR kinases, e.g., the ATR inhibitors VE-821 and VE-822 (Prevo et al. 2012; Pires et al. 2012; Fokas et al. 2012) or the CHK1/2 inhibitor AZD7762 (Zabludoff et al. 2008; Mitchell et al. 2010; Morgan et al. 2010). Other targets within the DDR network are the PARPs as this class of enzymes is involved in repair of DNA single-strand breaks (SSBs) — a kind of DNA damage commonly induced by ionizing radiation. Indeed, several PARP inhibitors, such as olaparib (AZD-2281) and veliparib (ABT-888), have revealed great potentials in terms of sensitizing tumor cells to irradiation in combined modality approaches (Donawho et al. 2007; Barazzuol et al. 2013; Miura et al. 2012; Chalmers et al. 2004; Senra et al. 2011; Shelton et al. 2013) and are, therefore, tested in clinical trials (Audeh et al. 2010; Tutt et al. 2010; Kaye et al. 2012). Recently, a specific inhibitor of the non-homologous end joining (NHEJ)-associated DNA ligase IV has been published (Srivastava et al. 2012) and showed great potency in terms of radiosensitizing cancer cells both in vitro and in vivo (Srivastava et al. 2012). Further studies are needed in order to see whether this inhibitor is feasible for clinical purposes.

Meanwhile, the small-molecule-inhibitor-based interference with DDR function might also offer the possibility to specifically target cancer stem cells (CSCs) - a small subset of the tumor cell population that shares several features with normal stem cells, e.g., the potential to selfrenew, to proliferate excessively, to differentiate into multiple cellular lineages, and to induce de novo formation of blood vessels (Reya et al. 2001; Jordan et al. 2006).
CSCs have moved into the focus of targeted therapies in recent years since complete eradication of a tumor inevitably demands for elimination of this particular kind of tumor cells that have the potential to self-renew and, in consequence, exhibit clonogenicity. Notably, CSCs exhibit an enormously high level of radioresistance (Bao et al. 2006; Firat et al. 2011), but the underlying mechanisms are unknown. It has been suggested that lower levels of ROS generated within the CSCs contribute to their high degree of radioresistance as well as to their enormous capacity to cope with DNA damages (Bao et al. 2006; Diehn et al. 2009). Very recently, it has been reported that CSCs exhibit a great enhancement in ATM kinase activity, suggesting that ATM might be a valuable target for combined modality approaches aiming at overcoming CSC radioresistance (Yin and Glass 2011). Indeed, Yin and Glass show that the inhibition of ATM by a small-molecule inhibitor reduces the radioresistance of CSCs (Yin and Glass 2011), thereby offering novel therapeutic perspectives. Aside, multiple signal transduction pathways that are important for the development of non-transformed stem cells, including the notch-, the hedgehog-, and the Wnt-/ $\beta$-catenin pathway, have been reported to contribute to radioresistance in CSCs (Chen et al. 2007; Phillips et al. 2006; Woodward et al. 2007; Wesbuer et al. 2010; Cerdan and Bhatia 2010). This might offer additional prospects for combinatorial approaches in future.

\section{Combination of RTX with agents targeting topoisomerases}

Topoisomerases represent a class of enzymes that regulate the topology of DNA, e.g., during processes such as replication, transcription, recombination, and DNA repair. While topoisomerase I (Topo I) coordinates relaxation of superhelical DNA by introducing single-strand breaks (nicks) within the DNA duplex, topoisomerase II (Topo II) introduces transient double-strand breaks, thereby disentangling coiled DNA (Champoux 2001). As these functions are crucial both for the integrity and for the propagation of genomes, topoisomerases became one of the first classes of enzymes targeted in cancer therapy. Primarily, inhibitors that were derived from camptothecin (inhibits topoisomerase I) and etoposide/VP-16 (inhibits topoisomerase II) were deployed to target the function of topoisomerases. Aside from their immense chemotherapeutic potential per se, these drugs also turned out to possess an excellent potential in terms of sensitizing tumor cells toward ionizing radiation (Chen et al. 1999). In parallel, several synthetic analogues, such as topotecan and irinotecan, were raised and investigated for clinical purposes (Pommier 2013). The results obtained confirmed the notion that pharmaceutical inhibition of topoisomerases provides a good opportunity for combined modality treatment of multiple kinds of neoplasms (Mattern 
et al. 1991; Kim et al. 1992; Choy and MacRae 2001). This explains why respective combinations have been and still are enduringly tested within clinical trials (O'Leary and Muggia 1998; Hande 1998; Tao et al. 2013). In addition, multiple other classes of topoisomerase inhibitors, such as quinolines (inhibitors of topoisomerase I), quinolones, and anthracyclines (inhibitors of topoisomerase II), have been deployed for clinical purpose (Pommier 2013).

\section{Combination of RTX with agents targeting the apoptosis network}

As the induction of cell death—at least in part—depends on the functionality of the apoptotic machinery, drugs that can directly stimulate apoptosis (for instance, by facilitating caspase activation) also moved into the view of clinically oriented research, especially as it can be assumed that targeting of apoptotic network components should efficiently sensitize tumor cells toward ionizing radiation. Moreover, many kinds of tumor cells circumvent efficient induction of apoptosis by down-regulation of pro-apoptotic genes or up-regulation of antiapoptotic ones (Kasibhatla and Tseng 2003). One prominent target among these components is the TNF- $\alpha$-related apoptosis-inducing ligand (TRAIL/Apo2L). For several tumor cell lines, it could be shown that both recombinant TRAIL itself and TRAIL-receptor agonistic antibodies, e.g., mapatumumab and lexatumumab, efficiently sensitize tumor cells to ionizing radiation (Belka et al. 2001; Chinnaiyan et al. 2000; Gong and Almasan 2000; Marini et al. 2009a, b; Niyazi et al. 2009a, b). In particular, cells that displayed only weak responses to either treatment alone often showed strong sensitization effects while no effect could be detected for non-transformed cells, which is-at least in part-due to the high level of selectivity of TRAIL and TRAIL-receptor agonizing antibodies for malignant cells. Another class of proteins involved in the regulation of apoptosis and therefore representing a promising target for combined modality approaches are the members of the B-cell lymphoma 2 (Bcl-2) family (Vogler et al. 2009). This protein family regulates the permeabilization of the outer mitochondrial membrane-a prerequisite for apoptosis induction via the intrinsic pathway. Therefore, inhibition of antiapoptotic Bcl-2 proteins should enhance the induction of apoptosis, especially when being combined with irradiation. In fact, several studies showed that inhibition of Bcl-2 sensitizes tumor cells toward ionizing radiation (Zerp et al. 2009; Moretti et al. 2010), revealing that Bcl-2 and, possibly, other members of this protein family may serve as candidates for targeted approaches in the future. Currently, navitoclax (ABT-263), a highly selective Bcl-2 inhibitor, is tested in clinical trials, and initial results strengthen the hope for its future implementation in the clinic (Gandhi et al. 2011; Rudin et al. 2012). A third class of compounds known to promote both intrinsic activation of apoptosis and radiosensitization are phospholipid analogues, such as the membrane-targeted alkylphosphocholines miltefosine and perifosine (Hilgard et al. 1997; Unger et al. 1989). The radiosensitizing capacity of this kind of drugs has already been proven in multiple tumor entities (Gao et al. 2011; Henke et al. 2012; Vink et al. 2006, 2007; Berkovic et al. 1997; Ruiter et al. 1999; Rubel et al. 2006).

\section{Combination of RTX with agents targeting cell division}

The cell cycle phase in which cell division takes place (Mphase) is considered to be the most vulnerable state in terms of radiotherapeutic intervention as it is well acknowledged that the sensitivity of cells to ionizing radiation peaks at this cell cycle stage (Sinclair and Morton 1966; Terasima and Tolmach 1963). Therefore and because of the fact that tumor cells, in contrast to most other nontransformed cell types, divide extensively, ancient approaches already aimed at arresting tumor cells within M-phase in order to achieve a maximum in radiosensitivity. For this purpose, drugs mainly derived from natural origin, such as taxol/paclitaxel, colchicine, and colcemid, were initially used. These compounds interfere with microtubule dynamics, thereby preventing accurate execution of cell division which results in a permanent arrest of the cells within M-phase. As to be expected, several of these drugs exhibited synergistic effects when being combined with exposure to ionizing radiation (Griem and Malkinson 1966; Brues et al. 1940; Tishler et al. 1992; Milas et al. 1994, 1996; Milross et al. 1997). This is why some of them (e.g., taxol) not only are adopted in radiochemotherapy but even still are in the focus of current clinical research (Pergolizzi et al. 2011; Combs et al. 2012). However, these drugs not only lack the level of specificity current therapies demand for, but they also exhibit side effects, which, in worst case, even limit the therapeutic effort. Progression through M-phase and the process of cell division itself both depend on the function of a multitude of cellular proteins including many protein kinases, which offers great opportunities for pharmaceutical intervention. In recent years, small-molecule inhibitors targeting protein kinases, which function more or less exclusively during cell division (e.g., Aurora kinases and Polo-like kinases), were designed and tested for their utility in combinatorial approaches. In these studies, several compounds, e.g., the Aurora kinase inhibitors AZD1152 (Barasertib), VX-680 (Tozasertib), and MLN8054, as well as the Polo-like kinase-1 inhibitor BI2536, have proven radiosensitizing potential (Moretti et al. 2011; Tao et al. 2008, 2009; Guan et al. 2007; Harris et al. 2012), nourishing the hope for their future implementation in the clinic. 
Combination of RTX with agents targeting the heat shock response

Heat shock proteins (HSPs) are molecular chaperones that catalyze the proper folding of other proteins and thereby avoid protein aggregations within cells. HSPs are often overexpressed in tumor cells as these cells are characterized by an overall increased level of protein synthesis, thus necessitating effective chaperone function in order to prevent misfolding and/or aggregation of proteins in these cells. In addition, HSP expression can be induced in response to multiple physiological or environmental insults, including irradiation, hypoxia, and/or chemical stress (Young et al. 2004). In this context, HSPs frequently function in an antiapoptotic fashion by associating with key components of the apoptotic machinery, thereby interfering with efficient apoptosis induction. For example, HSP70 and HSP90 can interfere with caspase-dependent and caspaseindependent apoptosis induction as well as by binding to the pro-apoptotic proteins Apaf-1 and apoptosis-inducing factor (AIF) (Garrido et al. 2006).

These findings explain why compounds that obstruct HSP function came into the focus of clinical research in recent years. Initially, naturally derived inhibitors targeting HSPs, such as geldanamycin and radicicol, were tested for clinical purposes but turned out to exhibit fatal side effects such as liver toxicity, thus precluding their implementation in the clinic. Therefore, novel compounds have been designed molecularly in order to minimize these kinds of side effects concomitant with a maximum in HSP-inhibiting capacity (Chiosis et al. 2006). Among those, inhibitors of HSP90 such as 17-N-allylamino-17-demethoxygeldanamycin (17-AAG), 17-dimethylaminoethylamino17-demethoxygeldanamycin (17-DMAG), or NVPAUY922, in particular, exhibited convincing potential in promoting tumor cell death as well as in sensitizing tumor cells to ionizing radiation (Bisht et al. 2003; Bull et al. 2004; Russell et al. 2003; Machida et al. 2005; Matsumoto et al. 2005; Kabakov et al. 2008; Stingl et al. 2010; Milanovi et al. 2013).

\section{Combination of RTX with agents targeting the EGFR pathway}

Another promising target for combined modality approaches is the EGFR, one member of the epithelial tyrosine kinase-associated membrane receptor family, and its downstream signaling pathways (Davies et al. 1980). Activation of EGFR leads to cell proliferation, inhibition of apoptosis, and angiogenesis. EGFR expression is commonly increased in human cancers (Wernicke et al. 2010), and preclinical evidence suggests a direct impact of EGFR on the sensitivity of tumor cells toward ionizing radiation
(Milas et al. 2000; Akimoto et al. 1999). In accordance, the expression of EGFR was reported to be up-regulated in response to irradiation, which might attenuate the effectiveness of fractionated radiotherapy (Fedrigo et al. 2011). Indeed, overexpression as well as mutations in the EGFR gene was shown to directly correlate with tumor radioresistance and poor clinical prognosis (Lammering et al. 2004; Giralt et al. 2005). Therefore, the EGFR pathway exhibits great influence on the overall effect that can be achieved by clinical irradiation, which in turn offers great opportunities for pharmaceutical intervention. Various kinds of EGFR-inhibiting molecules, such as the monoclonal antibodies cetuximab and panitumumab as well as the tyrosine kinase inhibitors erlotinib and gefitinib, have been developed and demonstrated great therapeutic benefit both in preclinical reports and in randomized clinical trials when combined with ionizing radiation. Therefore, EGFR inhibition meanwhile has become an established part of the clinical routine in radiation oncology (Nieder et al. 2012).

\section{Combination of RTX with agents targeting the tumor micromilieu}

Solid tumors are usually composed of tumor cells and several other cell types that form the tumor micromilieu. Both the formation and the progression of a solid tumor depend on the tight interaction between transformed tumor cells and the cells in the tumor microenvironment. By secreting growth factors and cytokines that target endothelial cells, fibroblasts, and other cell types within the microenvironment, tumor cells actively shape their surrounding milieu, for instance by inducing de novo formation of blood vessels and extracellular matrices (Carmeliet and Jain 2011). Moreover, tumor cells can also acquire the capacity to skew or evade antitumor immune responses and even to induce a milieu of immune tolerance (Dunn et al. 2004).

The complex interplay between tumor cells and the tumor stroma has strong impact on the tumor's sensitivity to exposure to ionizing radiation and, therefore, on longterm tumor control following radiotherapeutic attendance. In this respect, understanding the effects of ionizing radiation on the tumor microenvironment rather than on isolated tumor cells is one of the greatest interests in current radiobiological science. One promising candidate for radiotherapeutic approaches is the tumor microvasculature (Garcia-Barros et al. 2003). Recent reports suggest that directly targeting angiogenesis might increase the therapeutic ratio when being combined with irradiation (Beal et al. 2011). In accordance, the monoclonal antibody bevacizumab, which blocks angiogenesis by preventing the binding of VEGF to its respective receptor (Willett et al. 2004), significantly improves clinical outcome when 
combined with radiotherapy (Velenik et al. 2011; Shin et al. 2011; Niyazi et al. 2012a), and similar results were obtained for the VEGF-R inhibitor vandetanib and, primarily, for the antiangiogenetic peptide cilengitide (Albert et al. 2006; Williams et al. 2004; Brazelle et al. 2006; Drappatz et al. 2010; Yang et al. 2010). However, a recent phase III trial on cilengitide in combination with radiochemotherapy failed to show a significant increase in overall survival in glioblastoma patients.

Another mediator of the microenvironment's response to irradiation is transforming growth factor- $\beta$ (TGF- $\beta$ ), which is activated in response to ROS (Barcellos-Hoff and Dix 1996). TGF- $\beta$ regulates the proliferation, the differentiation, and the migration of cells (Massagué et al. 2000) and also contributes to metastasis and cell invasion (Heldin et al. 2009; Pardali and Moustakas 2007). This explains why interfering with TGF- $\beta$ signaling may decrease tumor cell growth, as well as their motility and their metastasizing capacity (Ikushima and Miyazono 2010). Thus, inhibition of TGF- $\beta$ can actively modulate the tumors' response to ionizing radiation, thereby providing an interesting tool for combinatorial approaches (Flanders and Burmester 2003; Rabbani et al. 2003; Xavier et al. 2004).

\section{Side effects}

As exposure to ionizing radiation induces cell death, radiotherapy inevitably coincides with side effects, including degeneration of normal tissues, acute inflammation, and even fibrotic tissue remodeling. The implementation of modern techniques such as IMRT has greatly facilitated the reduction in these classical kinds of side effects. On the other hand, novel, combined modality approaches that employ novel, molecularly designed compounds have led to rise of new, so far unknown side effects.

\section{Classical side effects}

Both acute inflammation and chronic fibrosis are classical side effects that coincide with the radiotherapeutic treatment of neoplasms and may limit radiation doses and thus the efficacy of the treatment (Abratt et al. 2004; Plathow et al. 2004; Abdollahi et al. 2005). In some cases, e.g., lung cancer, dose limitations due to the restricted tolerance of normal tissues even preclude successful radiotherapy in many patients with advanced disease progression (McDonald et al. 1995; Rosenzweig et al. 2000). In general, the severity of irradiation-induced pneumonitis depends on treatment factors, such as totality of the dose, the volume of irradiated lung, the schedule of fractionation, and the chemotherapy administered (Taghian et al. 2001; Rosen et al. 2001; Shi et al. 2010; Blom Goldman et al.
2010), but also on patient- and/or disease-related factors, such as preexisting lung diseases, poor pulmonary function, or genetic predispositions (Movsas et al. 1997; Mertens et al. 2002; Abratt et al. 2004). However, the mechanisms underlying these side effects are still poorly understood.

Although irradiation-induced primary damages in target cells such as apoptosis and necrosis have been sufficiently documented (Eriksson and Stigbrand 2010; McBride 1995), subsequent biological reactions in irradiated organs are quite sophisticated and not well defined (Lindroos et al. 1995; Zhang and Phan 1996). Recent studies suggest that cytokine cascades that govern the signaling pathways involved in irradiation response may play a pivotal role within these processes (Pohlers et al. 2009; Li et al. 2007; Lee et al. 2010), and a growing body of evidence demonstrates an increased expression of cytokines in radiationinduced pulmonary lesions (Johnston et al. 1996; Abdollahi et al. 2005). Among these, some pro-inflammatory cytokines such as the TNF- and the CD95 ligands are of importance for acute inflammation (Johnston et al. 1996; Heinzelmann et al. 2006), while others, such as TGF- $\beta$ and PDGF, are more involved in the regulation of chronic fibrotic response (Abdollahi et al. 2005; Dancea et al. 2009).

Recently described strategies that directly interfere with intracellular signaling pathways have revealed encouraging results in terms of attenuating radiation-caused side effects (Abdollahi et al. 2005; Anscher et al. 2008; Puthawala et al. 2008). However, as the cytokine signaling pathways that are activated in response to irradiation are broadly overlapping, rather than being independent of each other, it is unlikely that a complete blockage of these reactions can be achieved by blocking only one of them ( $\mathrm{Li}$ et al. 2009; Wynn 2008). Thus, multitargeted agents should exhibit higher effectiveness in attenuation of radiation-induced inflammation and fibrogenesis.

Novel side effects due to employment of targeted agents

With the increase in clinical relevance of novel, molecularly targeted agents, novel kinds of side effects are emerging (Niyazi et al. 2011b). Unfortunately, clinical data that would allow the assessment of these side effects are scarce. Additionally, the heterogeneity of both targeted agents and study designs does not allow abstraction these side effects. The examples presented here are meant to give an insight into the wide variety of side effects that may arise due to employment of targeted agents.

On the one hand, huge clinical trials exist for targeted agents such as trastuzumab, a humanized monoclonal antiher-2/neu antibody approved for the treatment of her- $2 /$ neu-positive breast cancers, showing no significant additional effects if being combined with radiation in a short- 
time follow-up (Halyard et al. 2009). On the other hand, there are agents such as sorafenib or erlotinib belonging to the group of kinase inhibitors for which toxicity data upon combined usage are extremely rare. However, case reports exist, in which combinational or sequential application of radiotherapy and kinase inhibitors were shown to lead to severe or even fatal toxicities such as diarrhea (Silvano et al. 2008), bowel perforation (Peters et al. 2008), and bronchial fistula (Basille et al. 2010).

The most prominent and rather well-documented example of a non-classical side effect can be observed for the EGFR-antagonizing antibody cetuximab which, for example, has been successfully used in combination with radiotherapy for the treatment of head and neck cancers (Bonner et al. 2006). In the trial conducted by Bonner and colleagues, a significant improvement in overall survival of patients that were treated with radioimmunotherapy was observed when compared to patients treated with radiotherapy alone. During this trial, the combinational treatment was reported to be rather well tolerated; however, during the years of clinical use, multiple reports pointing out an increase in skin toxicity and cases of even severe skin toxicity have been published (Walsh et al. 2011; Koutcher et al. 2009; Giro et al. 2009; Berger and Belka 2008).

Another targeted agent that exemplifies the heterogeneity of putative toxicities is the VEGF-antagonizing antibody bevacizumab that is used in combination with radiotherapy in different anatomical regions. Promising attempts were made in the combination of radiotherapy with bevacizumab for the treatment of (recurrent) glioblastomas (Beal et al. 2011; Vredenburgh et al. 2012). While no increased infield bleeding was reported for the application of ionizing radiation to the CNS, some cases of wound dehiscence of the previously operated site as well as increased levels of toxicity at late stages with some cases of optic neuropathy and one single case of Brown-Séquard syndrome have been documented (Gutin et al. 2009; Niyazi et al. 2012a; Lai et al. 2008; Kelly et al. 2011). Concerning the combination of bevacizumab and radiotherapy in case of the gastrointestinal tract, some studies pointed out an increased toxicity level, such as ischemic bowel complications (Lordick et al. 2006), mucosal tumor-associated bleeding (Crane et al. 2010), GI-bleeding, ulceration (Crane et al. 2010), and wound complications (Dipetrillo et al. 2012). Finally, in case of the mediastinal region, an increased rate of tracheoesophageal fistula has been reported (Spigel et al. 2010).

\section{Prognosis and prediction}

To date, therapeutic decisions are taken on increasing individualized and personalized bases. Important criteria in this regard are markers that help to predict the overall prognosis of the patient, the potential success of a particular kind of therapy, and the occurrence of unwanted side effects. In particular, the combination of ionizing radiation with molecularly targeted agents requires an a priori identification of patients that will benefit most (or at all) from a respective therapy. Here, classical parameters such as age, tumor node metastasis (TNM) stage, and histology of the tumor might not be sufficient, and additional information concerning the molecular tumor characteristics is needed in order to find the best therapeutic approach for the individual patient. "Prognostic" markers, in general, provide information concerning the natural course of the respective disease independently of the treatment applied. In contrast, the term "predictive" refers to markers for which it is likely that a specific subgroup among the patient collective will benefit from a certain intervention. For example, the EGFR1 mutation has a predictive value in adeno-NSCLC patients, but not a prognostic one (Oldenhuis et al. 2008).

\section{Biomarkers for tumors}

In patients with malignant gliomas, it should be of standard to test for the mutational status of the genes encoding for isocitrate dehydrogenases 1 and 2 (IDH-1/-2) as well as for codeletion of the $1 \mathrm{p} / 19 \mathrm{q}$ loci. While mutations within the IDH-1/-2 genes can be found in more than $70 \%$ of all primary astrocytomas (WHO grades II/III), oligodendrogliomas, and secondary glioblastomas, the respective mutation rate is only about $5 \%$ in primary glioblastomas and mutations within IDH-1/-2 are associated with positive clinical prognosis in astrocytoma and glioblastoma (Yan et al. 2009; Combs et al. 2011). In parallel, the codeletion of $1 \mathrm{p} / 19 \mathrm{q}$ was shown to correlate with reduced tumor aggressiveness and better response in anaplastic oligodendroglioma (Cairncross et al. 2006; Quon and Abdulkarim 2008; van den Bent et al. 2006). In addition, also the methylation status of the O-(6)-methylguanine-DNA methyltransferase (MGMT) gene promoter should be investigated. MGMT is a DNA-repairing enzyme that decreases the effects achievable by alkylating agent (e.g., temozolomide)-based chemotherapy (Esteller et al. 2000). Temozolomide is routinely used for concomitant radiochemotherapy in malignant gliomas as it was shown that combining temozolomide with radiotherapy results in significant prolongation of patient survival (Hegi et al. 2005; Stupp et al. 2009). As methylation of the MGMT promoter represses the expression of MGMT, this leads to a better response and thus, the methylation status of the MGMT promoter should be tested in routine before starting a temozolomide-based therapy.

Carcinogenesis in squamous cell carcinomas of the head and neck (HNSCC) can be linked either to the frequent use 
of tobacco and alcohol or to human papillomavirus (HPV) infection. In HPV-positive tumors, p53 and pRB tumorsuppressor function is blocked by viral proteins called E6 and E7, respectively, culminating in high levels of genome instability and increased expression of the senescenceassociated Cdk1-inhibitor p16 ${ }^{\text {Ink4a }}$. Detection of the HPV status can be accomplished by real-time PCR, and $\mathrm{p} 16^{\text {Ink4a }}$ can be detected by immunohistochemistry (Snow and Laudadio 2010). Approximately one-quarter of all HNSCC patients are positive for HPV (Deacon et al. 1984), and in oropharyngeal carcinomas, the prevalence of a positive HPV status is even around $40 \%$. Moreover, HPV-positive tumors not only genetically differ from negative ones (Martinez et al. 2007), but they also differ in terms of capacity to cope with DNA damage which is reduced in the HPV-positive tumors (Rieckmann et al. 2013). This can also explain, at least in part, why the HPV status is such an important prognostic factor in HNSCC patients, as it is often associated with superior outcome in case of patients treated with surgery followed by adjuvant radiotherapy or definitive radiochemotherapy (Ihloff et al. 2010; Fischer et al. 2010; Prestwich et al. 2010).

\section{Biomarkers for side effects}

One limitation in the radiotherapeutic treatment for malignant tumors is given by the need to minimize toxic effects that may harm normal tissues. In this context, late complications are of special importance because of frequently showing progression and thus association with long-life risk (Jung et al. 2001). Meanwhile, the extent of tissue toxicity introduced by irradiation greatly varies among different patients. Even though inherited hypersensitivity syndromes such as ataxia telangiectasia and the Nijmegen breakage syndrome that are characterized by severe side effects are rare, a wide range of reactions within normal tissues can be detected among the standard population. It was suggested that such individual variations in radiosensitivity are caused by genetic differences, such as single nucleotide polymorphisms (SNPs) (Turesson et al. 1996; Safwat et al. 2002). As these may serve as markers that would allow for estimating the individual risk of radiation-induced toxicity to non-transformed tissues, extensive efforts were made to identify such markers. Indeed, several SNPs could be identified that show tight relation with the degree of radiotoxicity as exemplified by SNPs that reside in the IL12RB2 and the ABCA1 genes (Isomura et al. 2008) as well as within the ATM gene (Edvardsen et al. 2007; Xiong et al. 2012). However, the studies performed so far often give rise to heterogeneous and/or even conflicting results. This can be seen for instance by the C-509 $\mathrm{T}$ polymorphism, an extensively studied SNP of the TGF $\beta 1$-encoding gene, for which conflicting results have been reported regarding its role in promoting inflammatory and fibrotic effects (Quarmby et al. 2003; Andreassen et al. 2005; De Ruyck et al. 2006; Barnett et al. 2010; Martin et al. 2010). Moreover, it was shown that significant coincidence of SNP occurrence and tissue toxicity is only found when several SNPs and/or other risk alleles are combined (Alsner et al. 2008; Andreassen et al. 2006; Zschenker et al. 2010). However, these data also have been contradicted by other studies (Raabe et al. 2012; Barnett et al. 2012). Therefore, analyzing the presence of SNPs as biomarkers that allow for individual prediction of side effects is still far from routine.

Personalized medicine: imaging for prognosis and prediction

$\left[{ }^{18} \mathrm{~F}\right]$ FDG-PET imaging has become the standard in oncologic treatment over the recent years especially for staging purposes due to its higher sensitivity and specificity if being compared to conventional imaging modalities such as CT and MRI. PET tracers may serve as prognostic and predictive markers for estimating responsiveness to radiotherapy or combined radiochemotherapy (Bussink et al. 2011). The outcome of head and neck cancer patients has been related to standardized uptake value (SUV) changes in PET imaging (Allal et al. 2004). Several tumor entities have been described in which PET gives early information as a marker for pathological response, especially in the cases of rectal cancer (de Geus-Oei et al. 2009), NSCLC (Pottgen et al. 2006), and esophageal cancer (Song et al. 2005). PET-CT was even described to be complimentary to conventional CT scan and able to predict early recurrences in breast cancer (Evangelista et al. 2011). Ongoing Hodgkin trials are in part based on PET imaging, and the stratification in these trials is done according to PET positivity after several chemotherapy cycles; however, this has still to be regarded as an experimental concept. Involvednode radiotherapy has been proposed as a means to further improve the therapeutic ratio by reduction of radiationinduced toxicity (Kobe et al. 2010) substantially based on proper PET/CT staging. Altogether, PET seems to be a substantial part of personalized medicine providing prognostic information and enabling the clinician to base treatment strategies on this information.

Meanwhile, PET-CT has gained an important place in radiotherapy planning (Yaromina and Zips 2010) as it provides detailed information about the tumor microenvironment in addition to anatomical imaging. In first instance, PET imaging data can be used for better delineation of the target volume. A second strategy, dose painting by contours (DPBC), consists in the creation of an additional PET-based target volume that is then treated with higher dose levels. In contrast, dose painting by 
numbers (DPBN) aims for a local variation in dose prescription according to the variation in the PET signal (Thorwarth et al. 2010). For instance, in case of lung cancer, several approaches already are available that directly depend on PET imaging (De Ruysscher et al. 2012). Currently, ${ }^{11} \mathrm{C}$-choline and occasionally ${ }^{18} \mathrm{~F}$ - or ${ }^{11} \mathrm{C}$ acetate are used as tracers for prostate cancer, reflecting the phospholipid metabolism (Pinkawa et al. 2011). ${ }^{11} \mathrm{C}$-choline-PET/CT might be considered as the imaging modality in radiation oncology to select and to delineate target volumes extending the prostate gland or fossa. In conjunction with IMRT and IGRT, it therefore might offer the opportunity for a dose escalation to selected sites while avoiding the irradiation of healthy tissues (Wurschmidt et al. 2011), and although the underlying assumption that PET correlates positively with more resistant subvolumes is still not proven for the broad variety of cancer types, data are coming forward that this is the case, e.g., in lung cancer. One open question is whether selective boosting with limited sensitivity of choline-PET indeed leads to higher tumor control rates (Niyazi et al. 2010).

Several trials are on their way to test PET imaging prospectively, e.g., in lung cancer [PET-PLAN trial (Fleckenstein et al. 2011)]. For malignant gliomas, FET-PET has been shown to significantly alter the target volumes (Niyazi et al. 2011a; Walter et al. 2012) and amino acid-PET in general, including 11C-methionine (MET)-PET, which was shown to be effective in target volume delineation (Grosu et al. 2005). The observation that meningioma cells overexpress the somatostatin receptor 2 (SSTR2) was the rationale to retrospectively analyze how far DOTATOC-PET/CT is helpful to improve target volume delineation for IMRT (Gehler et al. 2009). Many other tumor types are currently under investigation as PET provides additional information on tumor extent, involvement of lymph nodes, and putative distant metastases. Nevertheless, several problems have to be solved in the future, such as the inclusion of dynamic analyses and the correct procedures for thresholds.

\section{Conclusions}

Radiotherapy represents a crucial treatment option in the treatment for malignant diseases. In the recent years, the efficacy of radiotherapy has been improved by new techniques, among which IMRT and IGRT may constitute the most important ones. In parallel, novel approaches that combine radiotherapy with molecularly designed agents specifically targeting the hallmarks of cancer have been deployed and revealed promising results both in preclinical models and in clinical trials. However, employment of such targeted agents often coincides with new kinds of side effects demanding for biomarkers, which allow for detailed patient stratification. As the current availability of such markers is far from satisfying, efforts to identify novel candidates must be increased. In parallel, research focusing on multimodality approaches must be intensified as conventional radiochemotherapy has reached its limits.

Open Access This article is distributed under the terms of the Creative Commons Attribution License which permits any use, distribution, and reproduction in any medium, provided the original author(s) and the source are credited.

\section{References}

Abdollahi A, Li M, Ping G, Plathow C, Domhan S, Kiessling F, Lee LB, McMahon G, Grone HJ, Lipson KE, Huber PE (2005) Inhibition of platelet-derived growth factor signaling attenuates pulmonary fibrosis. J Exp Med 201(6):925-935

Abratt RP, Morgan GW, Silvestri G, Willcox P (2004) Pulmonary complications of radiation therapy. Clin Chest Med 25(1):167-177. doi:10.1016/S0272-5231(03)00126-6

Afshar G, Jelluma N, Yang X, Basila D, Arvold ND, Karlsson A, Yount GL, Dansen TB, Koller E, Haas-Kogan DA (2006) Radiation-induced caspase- 8 mediates p53-independent apoptosis in glioma cells. Cancer Res 66(8):4223-4232. doi:10.1158/ 0008-5472.can-05-1283

Akimoto T, Hunter NR, Buchmiller L, Mason K, Ang KK, Milas L (1999) Inverse relationship between epidermal growth factor receptor expression and radiocurability of murine carcinomas. Clin Cancer Res 5(10):2884-2890

Albain KS, Swann RS, Rusch VW, Turrisi AT 3rd, Shepherd FA, Smith C, Chen Y, Livingston RB, Feins RH, Gandara DR, Fry WA, Darling G, Johnson DH, Green MR, Miller RC, Ley J, Sause WT, Cox JD (2009) Radiotherapy plus chemotherapy with or without surgical resection for stage III non-small-cell lung cancer: a phase III randomised controlled trial. Lancet 374(9687):379-386. doi:10.1016/S0140-6736(09)60737-6

Albert JM, Cao C, Geng L, Leavitt L, Hallahan DE, Lu B (2006) Integrin $\alpha \mathrm{v} \beta 3$ antagonist Cilengitide enhances efficacy of radiotherapy in endothelial cell and non-small-cell lung cancer models. Int J Radiat Oncol Biol Phys 65(5):1536-1543. doi:10. 1016/j.ijrobp.2006.04.036

Allal AS, Slosman DO, Kebdani T, Allaoua M, Lehmann W, Dulguerov P (2004) Prediction of outcome in head-and-neck cancer patients using the standardized uptake value of 2-[18F]fluoro-2-deoxy-D-glucose. Int J Radiat Oncol Biol Phys 59(5):1295-1300. doi:10.1016/j.ijrobp.2003.12.039

Al-Sarraf M, LeBlanc M, Giri PG, Fu KK, Cooper J, Vuong T, Forastiere AA, Adams G, Sakr WA, Schuller DE, Ensley JF (1998) Chemoradiotherapy versus radiotherapy in patients with advanced nasopharyngeal cancer: phase III randomized Intergroup study 0099. J Clin Oncol 16(4):1310-1317

Alsner J, Andreassen CN, Overgaard J (2008) Genetic markers for prediction of normal tissue toxicity after radiotherapy. Semin Radiat Oncol 18(2):126-135. doi:S1053-4296(07)00095-1

Amichetti M, Amelio D, Minniti G (2012) Radiosurgery with photons or protons for benign and malignant tumours of the skull base: a review. Radiat Oncol 7(1):210. doi:10.1186/1748-717X-7-210

Andreassen CN, Alsner J, Overgaard J, Herskind C, Haviland J, Owen R, Homewood J, Bliss J, Yarnold J (2005) TGFB1 polymorphisms are associated with risk of late normal tissue complications in the breast after radiotherapy for early breast cancer. Radiother Oncol 75(1):18-21 
Andreassen CN, Alsner J, Overgaard M, Sorensen FB, Overgaard J (2006) Risk of radiation-induced subcutaneous fibrosis in relation to single nucleotide polymorphisms in TGFB1, SOD2, XRCC1, XRCC3, APEX and ATM-a study based on DNA from formalin fixed paraffin embedded tissue samples. Int $\mathbf{J}$ Radiat Biol 82(8):577-586

Anscher MS, Thrasher B, Zgonjanin L, Rabbani ZN, Corbley MJ, Fu K, Sun L, Lee WC, Ling LE, Vujaskovic Z (2008) Small molecular inhibitor of transforming growth factor-beta protects against development of radiation-induced lung injury. Int $\mathrm{J}$ Radiat Oncol Biol Phys 71(3):829-837

Apel A, Herr I, Schwarz H, Rodemann HP, Mayer A (2008) Blocked autophagy sensitizes resistant carcinoma cells to radiation therapy. Cancer Res 68(5):1485-1494. doi:10.1158/0008-5472. CAN-07-0562

Apel A, Zentgraf H, Buchler MW, Herr I (2009) Autophagy-A double-edged sword in oncology. Int J Cancer 125(5):991-995. doi:10.1002/ijc. 24500

Apetoh L, Ghiringhelli F, Tesniere A, Criollo A, Ortiz C, Lidereau R, Mariette C, Chaput N, Mira JP, Delaloge S, Andre F, Tursz T, Kroemer G, Zitvogel L (2007) The interaction between HMGB1 and TLR4 dictates the outcome of anticancer chemotherapy and radiotherapy. Immunol Rev 220:47-59

Audeh MW, Carmichael J, Penson RT, Friedlander M, Powell B, Bell-McGuinn KM, Scott C, Weitzel JN, Oaknin A, Loman N, Lu K, Schmutzler RK, Matulonis U, Wickens M, Tutt A (2010) Oral poly(ADP-ribose) polymerase inhibitor olaparib in patients with BRCA1 or BRCA2 mutations and recurrent ovarian cancer: a proof-of-concept trial. Lancet 376(9737):245-251. doi:10. 1016/S0140-6736(10)60893-8

Auer S, Hable V, Greubel C, Drexler GA, Schmid TE, Belka C, Dollinger G, Friedl AA (2011) Survival of tumor cells after proton irradiation with ultra-high dose rates. Radiat Oncol 6:139. doi:10.1186/1748-717X-6-139

Auperin A, Le Pechoux C, Rolland E, Curran WJ, Furuse K, Fournel P, Belderbos J, Clamon G, Ulutin HC, Paulus R, Yamanaka T, Bozonnat MC, Uitterhoeve A, Wang X, Stewart L, Arriagada R, Burdett S, Pignon JP (2010) Meta-analysis of concomitant versus sequential radiochemotherapy in locally advanced non-small-cell lung cancer. J Clin Oncol 28(13):2181-2190. doi:10.1200/JCO. 2009.26.2543

Bao S, Wu Q, McLendon RE, Hao Y, Shi Q, Hjelmeland AB, Dewhirst MW, Bigner DD, Rich JN (2006) Glioma stem cells promote radioresistance by preferential activation of the DNA damage response. Nature 444(7120):756-760

Barazzuol L, Jena R, Burnet NG, Meira LB, Jeynes JC, Kirkby KJ, Kirkby NF (2013) Evaluation of poly (ADP-ribose) polymerase inhibitor ABT-888 combined with radiotherapy and temozolomide in glioblastoma. Radiat Oncol 8(1):65. doi:10.116/1748$717 \mathrm{X}-8-65$

Barcellos-Hoff MH, Dix TA (1996) Redox-mediated activation of latent transforming growth factor-beta 1. Mol Endocrinol 10(9):1077-1083. doi:10.1210/me.10.9.1077

Barnett GC, Coles CE, Burnet NG, Pharoah PD, Wilkinson J, West CM, Elliott RM, Baynes C, Dunning AM (2010) No association between SNPs regulating TGF-betal secretion and late radiotherapy toxicity to the breast: results from the RAPPER study. Radiother Oncol 97(1):9-14. doi:S01678140(09)00664-1

Barnett GC, Coles CE, Elliott RM, Baynes C, Luccarini C, Conroy D, Wilkinson JS, Tyrer J, Misra V, Platte R, Gulliford SL, Sydes MR, Hall E, Bentzen SM, Dearnaley DP, Burnet NG, Pharoah PD, Dunning AM, West CM (2012) Independent validation of genes and polymorphisms reported to be associated with radiation toxicity: a prospective analysis study. Lancet Oncol 13(1):65-77. doi:S1470-2045(11)70302-3
Basille D, Andrejak M, Bentayeb H, Kanaan M, Fournier C, Lecuyer E, Boutemy M, Garidi R, Douadi Y, Dayen C (2010) Bronchial fistula associated with sunitinib in a patient previously treated with radiation therapy. Ann Pharmacother 44(2):383-386. doi:10.1345/aph.1M469

Basu B, Yap TA, Molife LR, de Bono JS (2012) Targeting the DNA damage response in oncology: past, present and future perspectives. Curr Opin Oncol 24(3):316-324. doi:10.1097/CCO. 0b013e32835280c6

Baudino TA, McKay C, Pendeville-Samain H, Nilsson JA, Maclean $\mathrm{KH}$, White EL, Davis AC, Ihle JN, Cleveland JL (2002) c-Myc is essential for vasculogenesis and angiogenesis during development and tumor progression. Genes Dev 16(19):2530-2543. doi:10.1101/gad.1024602

Beal K, Abrey L, Gutin P (2011) Antiangiogenic agents in the treatment of recurrent or newly diagnosed glioblastoma: analysis of single-agent and combined modality approaches. Radiat Oncol 6(1):2

Begg AC, Stewart FA, Vens C (2011) Strategies to improve radiotherapy with targeted drugs. Nat Rev Cancer 11(4):239-253

Belka C, Marini P, Budach W, Schulze-Osthoff K, Lang F, Gulbins E, Bamberg M (1998) Radiation-induced apoptosis in human lymphocytes and lymphoma cells critically relies on the upregulation of CD95/Fas/APO-1 ligand. Radiat Res 149(6): $588-595$

Belka C, Schmid B, Marini P, Durand E, Rudner J, Faltin H, Bamberg M, Schulze-Osthoff K, Budach W (2001) Sensitization of resistant lymphoma cells to irradiation-induced apoptosis by the death ligand TRAIL. Oncogene 20(17):2190-2196. doi:10. 1038/sj.onc. 1204318

Berger B, Belka C (2008) Severe skin reaction secondary to concomitant radiotherapy plus cetuximab. Radiat Oncol 3:5. doi:10.1186/1748-717X-3-5

Bergers G, Benjamin LE (2003) Tumorigenesis and the angiogenic switch. Nat Rev Cancer 3(6):401-410. doi:10.1038/nrc1093

Berkovic D, Grundel O, Berkovic K, Wildfang I, Hess CF, Schmoll HJ (1997) Synergistic cytotoxic effects of ether phospholipid analogues and ionizing radiation in human carcinoma cells. Radiother Oncol 43(3):293-301

Bernier J, Domenge C, Ozsahin M, Matuszewska K, Lefebvre JL, Greiner RH, Giralt J, Maingon P, Rolland F, Bolla M, Cognetti F, Bourhis J, Kirkpatrick A, van Glabbeke M (2004) Postoperative irradiation with or without concomitant chemotherapy for locally advanced head and neck cancer. $N$ Engl J Med 350(19):1945-1952. doi:10.1056/NEJMoa032641

Bin J, Allinger K, Assmann W, Dollinger G, Drexler GA, Friedl AA, Habs D, Hilz P, Hoerlein R, Humble N, Karsch S, Khrennikov K, Kiefer D, Krausz F, Ma W, Michalski D, Molls M, Raith S, Reinhardt S, Roper B, Schmid TE, Tajima T, Wenz J, Zlobinskaya O, Schreiber J, Wilkens JJ (2012) A laser-driven nanosecond proton source for radiobiological studies. Appl Phys Lett 101(24):243701-243704

Bisht KS, Bradbury CM, Mattson D, Kaushal A, Sowers A, Markovina S, Ortiz KL, Sieck LK, Isaacs JS, Brechbiel MW, Mitchell JB, Neckers LM, Gius D (2003) Geldanamycin and 17-allylamino17-demethoxygeldanamycin potentiate the in vitro and in vivo radiation response of cervical tumor cells via the heat shock protein 90-mediated intracellular signaling and cytotoxicity. Cancer Res 63(24):8984-8995

Blasco MA (2005) Telomeres and human disease: ageing, cancer and beyond. Nat Rev Genet 6(8):611-622. doi:10.1038/nrg1656

Blom Goldman U, Wennberg B, Svane G, Bylund H, Lind P (2010) Reduction of radiation pneumonitis by V20-constraints in breast cancer. Radiat Oncol 5:99. doi:10.1186/1748-717X-5-99

Bolla M, Collette L, Blank L, Warde P, Dubois JB, Mirimanoff RO, Storme G, Bernier J, Kuten A, Sternberg C, Mattelaer J, Lopez 
Torecilla J, Pfeffer JR, Lino Cutajar C, Zurlo A, Pierart M (2002) Long-term results with immediate androgen suppression and external irradiation in patients with locally advanced prostate cancer (an EORTC study): a phase III randomised trial. Lancet 360(9327):103-106

Bonner JA, Harari PM, Giralt J, Azarnia N, Shin DM, Cohen RB, Jones CU, Sur R, Raben D, Jassem J, Ove R, Kies MS, Baselga J, Youssoufian H, Amellal N, Rowinsky EK, Ang KK (2006) Radiotherapy plus cetuximab for squamous-cell carcinoma of the head and neck. N Engl J Med 354(6):567-578

Bortfeld T (1999) Optimized planning using physical objectives and constraints. Semin Radiat Oncol 9(1):20-34

Bouyon-Monteau A, Habrand JL, Datchary J, Alapetite C, Bolle S, Dendale R, Feuvret L, Helfre S, Calugaru V, Cosset JM, Bey P (2010) Is proton beam therapy the future of radiotherapy? Part I: clinical aspects. Cancer Radiother 14(8):727-738

Brada M, Pijls-Johannesma M, De Ruysscher D (2009) Current clinical evidence for proton therapy. Cancer J 15(4):319-324. doi:10.1097/PPO.0b013e3181b6127c

Brazelle WD, Shi W, Siemann DW (2006) VEGF-associated tyrosine kinase inhibition increases the tumor response to single and fractionated dose radiotherapy. Int J Radiat Oncol Biol Phys 65(3):836-841

Brues AM, Marble BB, Jackson EB (1940) Effects of colchicine and radiation on growth of normal tissues and tumors. Am J Cancer 38(2):159-168. doi:10.1158/ajc.1940.159

Bucci MK, Bevan A, Roach M 3rd (2005) Advances in radiation therapy: conventional to $3 \mathrm{D}$, to IMRT, to $4 \mathrm{D}$, and beyond. CA Cancer J Clin 55(2):117-134

Budach W, Hehr T, Budach V, Belka C, Dietz K (2006) A metaanalysis of hyperfractionated and accelerated radiotherapy and combined chemotherapy and radiotherapy regimens in unresected locally advanced squamous cell carcinoma of the head and neck. BMC Cancer 6:28

Bull EE, Dote H, Brady KJ, Burgan WE, Carter DJ, Cerra MA, Oswald KA, Hollingshead MG, Camphausen K, Tofilon PJ (2004) Enhanced tumor cell radiosensitivity and abrogation of G2 and S phase arrest by the Hsp90 inhibitor 17-(dimethylaminoethylamino)-17-demethoxygeldanamycin. Clin Cancer Res 10(23):8077-8084

Burnette BC, Liang $\mathrm{H}$, Lee $\mathrm{Y}$, Chlewicki L, Khodarev NN, Weichselbaum RR, Fu YX, Auh SL (2011) The efficacy of radiotherapy relies upon induction of type $\mathrm{i}$ interferon-dependent innate and adaptive immunity. Cancer Res 71(7):2488-2496. doi:10.1158/0008-5472.CAN-10-2820

Bussink J, Kaanders JH, van der Graaf WT, Oyen WJ (2011) PET-CT for radiotherapy treatment planning and response monitoring in solid tumors. Nat Rev Clin Oncol 8(4):233-242

Cairncross G, Berkey B, Shaw E, Jenkins R, Scheithauer B, Brachman D, Buckner J, Fink K, Souhami L, Laperierre N, Mehta M, Curran W (2006) Phase III trial of chemotherapy plus radiotherapy compared with radiotherapy alone for pure and mixed anaplastic oligodendroglioma: Intergroup Radiation Therapy Oncology Group Trial 9402. J Clin Oncol 24(18): 2707-2714

Camphausen K, Moses MA, Beecken WD, Khan MK, Folkman J, O'Reilly MS (2001) Radiation therapy to a primary tumor accelerates metastatic growth in mice. Cancer Res 61(5): 2207-2211

Campisi J, d'Adda di Fagagna F (2007) Cellular senescence: when bad things happen to good cells. Nat Rev Mol Cell Biol 8(9):729-740

Carmeliet P, Jain RK (2011) Principles and mechanisms of vessel normalization for cancer and other angiogenic diseases. Nat Rev Drug Discov 10(6):417-427
Cerdan C, Bhatia M (2010) Novel roles for Notch, Wnt and Hedgehog in hematopoesis derived from human pluripotent stem cells. Int $\mathrm{J}$ Dev Biol 54(6-7):955-963

Chadha M, Young A, Geraghty C, Masino R, Harrison L (2011) Image guidance using 3D-ultrasound (3D-US) for daily positioning of lumpectomy cavity for boost irradiation. Radiat Oncol 6:45. doi:10.1186/1748-717X-6-45

Chalmers A, Johnston P, Woodcock M, Joiner M, Marples B (2004) PARP-1, PARP-2, and the cellular response to low doses of ionizing radiation. Int J Radiat Oncol Biol Phys 58(2):410-419

Champoux JJ (2001) DNA topoisomerases: structure, function, and mechanism. Annu Rev Biochem 70:369-413

Chang F, Lee JT, Navolanic PM, Steelman LS, Shelton JG, Blalock WL, Franklin RA, McCubrey JA (2003) Involvement of PI3 K/ Akt pathway in cell cycle progression, apoptosis, and neoplastic transformation: a target for cancer chemotherapy. Leukemia 17(3):590-603. doi:10.1038/sj.leu.2402824

Chen AY, Choy H, Rothenberg ML (1999) DNA topoisomerase I-targeting drugs as radiation sensitizers. Oncology (Williston Park) 13(10 Suppl 5):39-46

Chen MS, Woodward WA, Behbod F, Peddibhotla S, Alfaro MP, Buchholz TA, Rosen JM (2007) Wnt/ $\beta$-catenin mediates radiation resistance of Sca1+ progenitors in an immortalized mammary gland cell line. J Cell Sci 120(3):468-477. doi:10. 1242/jcs.03348

Chin L, Tam A, Pomerantz J, Wong M, Holash J, Bardeesy N, Shen Q, O'Hagan R, Pantginis J, Zhou H, Horner JW 2nd, CordonCardo C, Yancopoulos GD, DePinho RA (1999) Essential role for oncogenic Ras in tumour maintenance. Nature 400(6743):468-472. doi:10.1038/22788

Chinnaiyan AM, Prasad U, Shankar S, Hamstra DA, Shanaiah M, Chenevert TL, Ross BD, Rehemtulla A (2000) Combined effect of tumor necrosis factor-related apoptosis-inducing ligand and ionizing radiation in breast cancer therapy. Proc Natl Acad Sci USA 97(4):1754-1759. doi:10.1073/pnas.030545097

Chiosis G, Caldas Lopes E, Solit D (2006) Heat shock protein-90 inhibitors: a chronicle from geldanamycin to today's agents. Curr Opin Investig Drugs 7(6):534-541

Chipuk JE, Moldoveanu T, Llambi F, Parsons MJ, Green DR (2010) The BCL-2 family reunion. Mol Cell 37(3):299-310. doi:10. 1016/j.molcel.2010.01.025

Choy H, MacRae R (2001) Irinotecan and radiation in combinedmodality therapy for solid tumors. Oncology (Williston Park) 15(7 Suppl 8):22-28

Clasie B, Wroe A, Kooy H, Depauw N, Flanz J, Paganetti H, Rosenfeld A (2010) Assessment of out-of-field absorbed dose and equivalent dose in proton fields. Med Phys 37(1):311-321

Combs SE, Burkholder I, Edler L, Rieken S, Habermehl D, Jakel O, Haberer T, Haselmann R, Unterberg A, Wick W, Debus J (2010a) Randomised phase I/II study to evaluate carbon ion radiotherapy versus fractionated stereotactic radiotherapy in patients with recurrent or progressive gliomas: the CINDERELLA trial. BMC Cancer 10:533. doi:10.1186/1471-2407-10-533

Combs SE, Ellerbrock M, Haberer T, Habermehl D, Hoess A, Jakel O, Jensen A, Klemm S, Munter M, Naumann J, Nikoghosyan A, Oertel S, Parodi K, Rieken S, Debus J (2010b) Heidelberg Ion Therapy Center (HIT): initial clinical experience in the first 80 patients. Acta Oncol 49(7):1132-1140. doi:10.3109/0284186X. 2010.498432

Combs SE, Jakel O, Haberer T, Debus J (2010c) Particle therapy at the Heidelberg Ion Therapy Center (HIT) - Integrated researchdriven university-hospital-based radiation oncology service in Heidelberg, Germany. Radiother Oncol 95(1):41-44

Combs SE, Rieken S, Wick W, Abdollahi A, von Deimling A, Debus J, Hartmann C (2011) Prognostic significance of IDH-1 and 
MGMT in patients with glioblastoma: one step forward, and one step back? Radiat Oncol 6:115. doi:10.1186/1748-717X-6-115

Combs SE, Zipp L, Rieken S, Habermehl D, Brons S, Winter M, Haberer T, Debus J, Weber KJ (2012) In vitro evaluation of photon and carbon ion radiotherapy in combination with chemotherapy in glioblastoma cells. Radiat Oncol 7:9. doi:10. 1186/1748-717X-7-9

Cooper JS, Pajak TF, Forastiere AA, Jacobs J, Campbell BH, Saxman SB, Kish JA, Kim HE, Cmelak AJ, Rotman M, Machtay M, Ensley JF, Chao KS, Schultz CJ, Lee N, Fu KK (2004) Postoperative concurrent radiotherapy and chemotherapy for high-risk squamous-cell carcinoma of the head and neck. N Engl J Med 350(19):1937-1944. doi:10.1056/NEJMoa032646

Coppe JP, Desprez PY, Krtolica A, Campisi J (2010) The senescenceassociated secretory phenotype: the dark side of tumor suppression. Annu Rev Pathol 5:99-118. doi:10.1146/annurev-pathol121808-102144

Cordes N, Hansmeier B, Beinke C, Meineke V, van Beuningen D (2003) Irradiation differentially affects substratum-dependent survival, adhesion, and invasion of glioblastoma cell lines. Br J Cancer 89(11):2122-2132. doi:10.1038/sj.bjc.6601429

Cowell IG, Durkacz BW, Tilby MJ (2005) Sensitization of breast carcinoma cells to ionizing radiation by small molecule inhibitors of DNA-dependent protein kinase and ataxia telangiectsia mutated. Biochem Pharmacol 71(1-2):13-20

Crane CH, Eng C, Feig BW, Das P, Skibber JM, Chang GJ, Wolff RA, Krishnan S, Hamilton S, Janjan NA, Maru DM, Ellis LM, Rodriguez-Bigas MA (2010) Phase II trial of neoadjuvant bevacizumab, capecitabine, and radiotherapy for locally advanced rectal cancer. Int $\mathrm{J}$ Radiat Oncol Biol Phys 76(3):824-830. doi:10.1016/j.ijrobp.2009.02.037

Crehange G, Mirjolet C, Gauthier M, Martin E, Truc G, PeignauxCasasnovas K, Azelie C, Bonnetain F, Naudy S, Maingon P (2012) Clinical impact of margin reduction on late toxicity and short-term biochemical control for patients treated with daily online image guided IMRT for prostate cancer. Radiother Oncol 103(2):244-246. doi:10.1016/j.radonc.2011.10.025

Dancea HC, Shareef MM, Ahmed MM (2009) Role of radiationinduced TGF-beta signaling in cancer therapy. Mol Cell Pharmacol 1(1):44-56

Darby S, McGale P, Correa C, Taylor C, Arriagada R, Clarke M, Cutter D, Davies C, Ewertz M, Godwin J, Gray R, Pierce L, Whelan T, Wang Y, Peto R (2011) Effect of radiotherapy after breast-conserving surgery on 10-year recurrence and 15-year breast cancer death: meta-analysis of individual patient data for 10,801 women in 17 randomised trials. Lancet 378(9804):1707-1716. doi:10.1016/S0140-6736(11) 61629-2

Davies RL, Grosse VA, Kucherlapati R, Bothwell M (1980) Genetic analysis of epidermal growth factor action: assignment of human epidermal growth factor receptor gene to chromosome 7. Proc Natl Acad Sci USA 77(7):4188-4192

de Geus-Oei LF, Vriens D, van Laarhoven HW, van der Graaf WT, Oyen WJ (2009) Monitoring and predicting response to therapy with 18F-FDG PET in colorectal cancer: a systematic review. J Nucl Med 50(Suppl 1):43S-54S

De Ruyck K, Van Eijkeren M, Claes K, Bacher K, Vral A, De Neve W, Thierens H (2006) TGFbeta1 polymorphisms and late clinical radiosensitivity in patients treated for gynecologic tumors. Int J Radiat Oncol Biol Phys 65(4):1240-1248

De Ruysscher D, Nestle U, Jeraj R, Macmanus M (2012) PET scans in radiotherapy planning of lung cancer. Lung Cancer 75(2):141-145. doi:10.1016/j.lungcan.2011.07.018

Deacon J, Peckham MJ, Steel GG (1984) The radioresponsiveness of human tumours and the initial slope of the cell survival curve. Radiother Oncol 2(4):317-323
Debatin K-M, Krammer PH (2004) Death receptors in chemotherapy and cancer. Oncogene 23(16):2950-2966

Delaney G, Jacob S, Featherstone C, Barton M (2005) The role of radiotherapy in cancer treatment: estimating optimal utilization from a review of evidence-based clinical guidelines. Cancer 104(6):1129-1137. doi:10.1002/cncr.21324

Deville C, Ben-Josef E, Vapiwala N (2012) Radiation therapy modalities for prostate cancer. JAMA 308 (5):451; author reply $451-452$

Diamond MS, Kinder M, Matsushita H, Mashayekhi M, Dunn GP, Archambault JM, Lee H, Arthur CD, White JM, Kalinke U, Murphy KM, Schreiber RD (2011) Type I interferon is selectively required by dendritic cells for immune rejection of tumors. J Exp Med 208(10):1989-2003. doi:10.1084/jem. 20101158

Diehn M, Cho RW, Lobo NA, Kalisky T, Dorie MJ, Kulp AN, Qian D, Lam JS, Ailles LE, Wong M, Joshua B, Kaplan MJ, Wapnir I, Dirbas FM, Somlo G, Garberoglio C, Paz B, Shen J, Lau SK, Quake SR, Brown JM, Weissman IL, Clarke MF (2009) Association of reactive oxygen species levels and radioresistance in cancer stem cells. Nature 458(7239):780-783. doi:10.1038/ nature 07733

Dipetrillo T, Pricolo V, Lagares-Garcia J, Vrees M, Klipfel A, Cataldo T, Sikov W, McNulty B, Shipley J, Anderson E, Khurshid H, Oconnor B, Oldenburg NB, Radie-Keane K, Husain S, Safran H (2012) Neoadjuvant bevacizumab, oxaliplatin, 5 -fluorouracil, and radiation for rectal cancer. Int J Radiat Oncol Biol Phys 82(1):124-129. doi:10.1016/j.ijrobp.2010.08.005

Dollinger G, Bergmaier A, Hable V, Hertenberger R, Greubel C, Hauptner A, Reichart P (2009) Nanosecond pulsed proton microbeam. Nucl Instrum Methods Phys Res Sect B 267(12-13):2008-2012. doi:10.1016/j.nimb.2009.03.006

Donawho CK, Luo Y, Penning TD, Bauch JL, Bouska JJ, BontchevaDiaz VD, Cox BF, DeWeese TL, Dillehay LE, Ferguson DC, Ghoreishi-Haack NS, Grimm DR, Guan R, Han EK, HolleyShanks RR, Hristov B, Idler KB, Jarvis K, Johnson EF, Kleinberg LR, Klinghofer V, Lasko LM, Liu X, Marsh KC, McGonigal TP, Meulbroek JA, Olson AM, Palma JP, Rodriguez LE, Shi Y, Stavropoulos JA, Tsurutani AC, Zhu GD, Rosenberg SH, Giranda VL, Frost DJ (2007) ABT-888, an orally active poly(ADP-ribose) polymerase inhibitor that potentiates DNAdamaging agents in preclinical tumor models. Clin Cancer Res 13(9):2728-2737

Douillard JY, Rosell R, De Lena M, Carpagnano F, Ramlau R, Gonzales-Larriba JL, Grodzki T, Pereira JR, Le Groumellec A, Lorusso V, Clary C, Torres AJ, Dahabreh J, Souquet PJ, Astudillo J, Fournel P, Artal-Cortes A, Jassem J, Koubkova L, His P, Riggi M, Hurteloup P (2006) Adjuvant vinorelbine plus cisplatin versus observation in patients with completely resected stage IB-IIIA non-small-cell lung cancer (Adjuvant Navelbine International Trialist Association [ANITA]): a randomised controlled trial. Lancet Oncol 7(9):719-727

Drappatz J, Norden AD, Wong ET, Doherty LM, Lafrankie DC, Ciampa A, Kesari S, Sceppa C, Gerard M, Phan P, Schiff D, Batchelor TT, Ligon KL, Young G, Muzikansky A, Weiss SE, Wen PY (2010) Phase I study of vandetanib with radiotherapy and temozolomide for newly diagnosed glioblastoma. Int $\mathbf{J}$ Radiat Oncol Biol Phys 78(1):85-90. doi:10.1016/j.ijrobp.2009. 07.1741

Dunn GP, Old LJ, Schreiber RD (2004) The immunobiology of cancer immunosurveillance and immunoediting. Immunity 21(2):137-148. doi:10.1016/j.immuni.2004.07.017

Dunn GP, Koebel CM, Schreiber RD (2006) Interferons, immunity and cancer immunoediting. Nat Rev Immunol 6(11):836-848

Edvardsen H, Tefre T, Jansen L, Vu P, Haffty BG, Fossa SD, Kristensen VN, Borresen-Dale AL (2007) Linkage 
disequilibrium pattern of the ATM gene in breast cancer patients and controls; association of SNPs and haplotypes to radiosensitivity and post-lumpectomy local recurrence. Radiat Oncol $2: 25$

Eriksson D, Stigbrand T (2010) Radiation-induced cell death mechanisms. Tumor Biol 31(4):363-372. doi:10.1007/s13277010-0042-8

Esteller M, Garcia-Foncillas J, Andion E, Goodman SN, Hidalgo OF, Vanaclocha V, Baylin SB, Herman JG (2000) Inactivation of the DNA-repair gene MGMT and the clinical response of gliomas to alkylating agents. N Engl J Med 343(19):1350-1354. doi:10. 1056/NEJM200011093431901

Evangelista L, Baretta Z, Vinante L, Cervino AR, Gregianin M, Ghiotto C, Saladini G, Sotti G (2011) Tumour markers and FDG PET/CT for prediction of disease relapse in patients with breast cancer. Eur J Nucl Med Mol Imaging 38(2):293-301. doi:10. 1007/s00259-010-1626-7

Fedrigo CA, Grivicich I, Schunemann DP, Chemale IM, dos Santos D, Jacovas T, Boschetti PS, Jotz GP, Braga Filho A, da Rocha AB (2011) Radioresistance of human glioma spheroids and expression of HSP70, p53 and EGFr. Radiat Oncol 6:156. doi:10.1186/1748-717X-6-156

Firat E, Gaedicke S, Tsurumi C, Esser N, Weyerbrock A, Niedermann G (2011) Delayed cell death associated with mitotic catastrophe in gamma-irradiated stem-like glioma cells. Radiat Oncol $6(1): 71$

Fischer CA, Zlobec I, Green E, Probst S, Storck C, Lugli A, Tornillo L, Wolfensberger M, Terracciano LM (2010) Is the improved prognosis of p16 positive oropharyngeal squamous cell carcinoma dependent of the treatment modality? Int $\mathrm{J}$ Cancer 126(5):1256-1262. doi:10.1002/ijc.24842

Fisher B, Anderson S, Bryant J, Margolese RG, Deutsch M, Fisher ER, Jeong JH, Wolmark N (2002) Twenty-year follow-up of a randomized trial comparing total mastectomy, lumpectomy, and lumpectomy plus irradiation for the treatment of invasive breast cancer. N Engl J Med 347(16):1233-1241. doi:10.1056/ NEJMoa022152

Flanders KC, Burmester JK (2003) Medical applications of transforming growth factor- $\beta$. Clin Med Res 1(1):13-20. doi:10.3121/ cmr.1.1.13

Fleckenstein J, Hellwig D, Kremp S, Grgic A, Groschel A, Kirsch CM, Nestle U, Rube C (2011) F-18-FDG-PET confined radiotherapy of locally advanced NSCLC with concomitant chemotherapy: results of the PET-PLAN pilot trial. Int J Radiat Oncol Biol Phys 81(4):e283-e289

Fogarty GB, Ng D, Liu G, Haydu LE, Bhandari N (2011) Volumetric modulated arc therapy is superior to conventional intensity modulated radiotherapy-a comparison among prostate cancer patients treated in an Australian centre. Radiat Oncol 6:108. doi:10.1186/1748-717X-6-108

Fokas E, Prevo R, Pollard JR, Reaper PM, Charlton PA, Cornelissen B, Vallis KA, Hammond EM, Olcina MM, Gillies McKenna W, Muschel RJ, Brunner TB (2012) Targeting ATR in vivo using the novel inhibitor VE-822 results in selective sensitization of pancreatic tumors to radiation. Cell Death Dis 3:e441. doi:10. 1038/cddis.2012.181

Fontenot JD, Bloch C, Followill D, Titt U, Newhauser WD (2010) Estimate of the uncertainties in the relative risk of secondary malignant neoplasms following proton therapy and intensitymodulated photon therapy. Phys Med Biol 55(23):6987-6998

Foroudi F, Wilson L, Bressel M, Haworth A, Hornby C, Pham D, Cramb J, Gill S, Tai KH, Kron T (2012) A dosimetric comparison of $3 \mathrm{D}$ conformal vs intensity modulated vs volumetric arc radiation therapy for muscle invasive bladder cancer. Radiat Oncol 7:111. doi:10.1186/1748-717X-7-111
Foster RD, Pistenmaa DA, Solberg TD (2012) A comparison of radiographic techniques and electromagnetic transponders for localization of the prostate. Radiat Oncol 7:101. doi:10.1186/ 1748-717X-7-101

Frasca F, Pandini G, Sciacca L, Pezzino V, Squatrito S, Belfiore A, Vigneri R (2008) The role of insulin receptors and IGF-I receptors in cancer and other diseases. Arch Physiol Biochem 114(1):23-37. doi:10.1080/13813450801969715

Fresno Vara JA, Casado E, de Castro J, Cejas P, Belda-Iniesta C, Gonzalez-Baron M (2004) PI3 K/Akt signalling pathway and cancer. Cancer Treat Rev 30(2):193-204. doi:10.1016/j.ctrv. 2003.07.007

Frey B, Rubner Y, Wunderlich R, Weiss EM, Pockley AG, Fietkau R, Gaipl US (2012) Induction of abscopal anti-tumor immunity and immunogenic tumor cell death by ionizing irradiation-implications for cancer therapies. Curr Med Chem 19(12):1751-1764

Fuertes MB, Woo SR, Burnett B, Fu YX, Gajewski TF (2013) Type I interferon response and innate immune sensing of cancer. Trends Immunol 34(2):67-73. doi:10.1016/j.it.2012.10.004

Gandhi L, Camidge DR, de Oliveira MR, Bonomi P, Gandara D, Khaira D, Hann CL, McKeegan EM, Litvinovich E, Hemken PM, Dive C, Enschede SH, Nolan C, Chiu YL, Busman T, Xiong H, Krivoshik AP, Humerickhouse R, Shapiro GI, Rudin CM (2011) Phase I study of Navitoclax (ABT-263), a novel Bcl-2 family inhibitor, in patients with small-cell lung cancer and other solid tumors. J Clin Oncol 29(7):909-916

Ganswindt U, Paulsen F, Corvin S, Hundt I, Alber M, Frey B, Stenzl A, Bares R, Bamberg M, Belka C (2007) Optimized coverage of high-risk adjuvant lymph node areas in prostate cancer using a sentinel node-based, intensity-modulated radiation therapy technique. Int J Radiat Oncol Biol Phys 67(2):347-355

Gao Y, Ishiyama H, Sun M, Brinkman KL, Wang X, Zhu J, Mai W, Huang Y, Floryk D, Ittmann M, Thompson TC, Butler EB, Xu B, Teh BS (2011) The alkylphospholipid, perifosine, radiosensitizes prostate cancer cells both in vitro and in vivo. Radiat Oncol 6:39. doi: 10.1186/1748-717X-6-39

Garcia-Barros M, Paris F, Cordon-Cardo C, Lyden D, Rafii S, Haimovitz-Friedman A, Fuks Z, Kolesnick R (2003) Tumor response to radiotherapy regulated by endothelial cell apoptosis. Science 300(5622):1155-1159. doi:10.1126/science.1082504

Garcia-Lora A, Algarra I, Garrido F (2003) MHC class I antigens, immune surveillance, and tumor immune escape. J Cell Physiol 195(3):346-355. doi:10.1002/jcp.10290

Garrido C, Galluzzi L, Brunet M, Puig PE, Didelot C, Kroemer G (2006) Mechanisms of cytochrome c release from mitochondria. Cell Death Differ 13(9):1423-1433

Gehler B, Paulsen F, Oksuz MO, Hauser TK, Eschmann SM, Bares R, Pfannenberg C, Bamberg M, Bartenstein P, Belka C, Ganswindt U (2009) [68 Ga]-DOTATOC-PET/CT for meningioma IMRT treatment planning. Radiat Oncol 4:56. doi:10.1186/1748-717X4-56

Genesca A, Martin M, Latre L, Soler D, Pampalona J, Tusell L (2006) Telomere dysfunction: a new player in radiation sensitivity. BioEssays 28(12):1172-1180. doi:10.1002/bies.20501

Gill S, Thomas J, Fox C, Kron T, Rolfo A, Leahy M, Chander S, Williams S, Tai KH, Duchesne GM, Foroudi F (2011) Acute toxicity in prostate cancer patients treated with and without image-guided radiotherapy. Radiat Oncol 6:145. doi:10.116/ 1748-717X-6-145

Giralt J, de las Heras M, Cerezo L, Eraso A, Hermosilla E, Velez D, Lujan J, Espin E, Rosello J, Majo J, Benavente S, Armengol M, de Torres I (2005) The expression of epidermal growth factor receptor results in a worse prognosis for patients with rectal cancer treated with preoperative radiotherapy: a multicenter, retrospective analysis. Radiother Oncol 74(2):101-108 
Giro C, Berger B, Bolke E, Ciernik IF, Duprez F, Locati L, Maillard S, Ozsahin M, Pfeffer R, Robertson AG, Langendijk JA, Budach W (2009) High rate of severe radiation dermatitis during radiation therapy with concurrent cetuximab in head and neck cancer: results of a survey in EORTC institutes. Radiother Oncol 90(2):166-171. doi:10.1016/j.radonc.2008.09.007

Glatstein E (2002) Intensity-modulated radiation therapy: the inverse, the converse, and the perverse. Semin Radiat Oncol 12(3): 272-281

Goitein M (2008) Magical protons? Int J Radiat Oncol Biol Phys 70(3):654-656

Golding SE, Rosenberg E, Valerie N, Hussaini I, Frigerio M, Cockcroft XF, Chong WY, Hummersone M, Rigoreau L, Menear KA, O'Connor MJ, Povirk LF, van Meter T, Valerie K (2009) Improved ATM kinase inhibitor KU-60019 radiosensitizes glioma cells, compromises insulin, AKT and ERK prosurvival signaling, and inhibits migration and invasion. Mol Cancer Ther 8(10):2894-2902. doi:10.1158/1535-7163.MCT-09-0519

Gong B, Almasan A (2000) Apo2 ligand/TNF-related apoptosisinducing ligand and death receptor 5 mediate the apoptotic signaling induced by ionizing radiation in leukemic cells. Cancer Res 60(20):5754-5760

Greubel C, Assmann W, Burgdorf C, Dollinger G, Du G, Hable V, Hapfelmeier A, Hertenberger R, Kneschaurek P, Michalski D, Molls M, Reinhardt S, Roper B, Schell S, Schmid TE, Siebenwirth C, Wenzl T, Zlobinskaya O, Wilkens JJ (2011) Scanning irradiation device for mice in vivo with pulsed and continuous proton beams. Radiat Environ Biophys 50(3):339-344. doi:10.1007/s00411-011-0365-x

Griem ML, Malkinson FD (1966) Modification of radiation response of tissue by colchicine. A clinical evaluation. Am J Roentgenol Radium Ther Nucl Med 97(4):1003-1006

Grosu AL, Weber WA, Riedel E, Jeremic B, Nieder C, Franz M, Gumprecht H, Jaeger R, Schwaiger M, Molls M (2005) L-(methyl-11C) methionine positron emission tomography for target delineation in resected high-grade gliomas before radiotherapy. Int J Radiat Oncol Biol Phys 63(1):64-74

Guan Z, Wang XR, Zhu XF, Huang XF, Xu J, Wang LH, Wan XB, Long ZJ, Liu JN, Feng GK, Huang W, Zeng YX, Chen FJ, Liu Q (2007) Aurora-A, a negative prognostic marker, increases migration and decreases radiosensitivity in cancer cells. Cancer Res 67(21):10436-10444

Guckenberger M, Wulf J, Mueller G, Krieger T, Baier K, Gabor M, Richter A, Wilbert J, Flentje M (2009) Dose-response relationship for image-guided stereotactic body radiotherapy of pulmonary tumors: relevance of $4 \mathrm{D}$ dose calculation. Int $\mathrm{J}$ Radiat Oncol Biol Phys 74(1):47-54. doi:10.1016/j.ijrobp.2008. 06.1939

Gudkov AV, Komarova EA (2003) The role of p53 in determining sensitivity to radiotherapy. Nat Rev Cancer 3(2):117-129. doi:10.1038/nrc992

Gupta AK, Bakanauskas VJ, Cerniglia GJ, Cheng Y, Bernhard EJ, Muschel RJ, McKenna WG (2001) The Ras radiation resistance pathway. Cancer Res 61(10):4278-4282

Gupta T, Agarwal J, Jain S, Phurailatpam R, Kannan S, Ghosh-Laskar S, Murthy V, Budrukkar A, Dinshaw K, Prabhash K, Chaturvedi P, D’Cruz A (2012) Three-dimensional conformal radiotherapy (3D-CRT) versus intensity modulated radiation therapy (IMRT) in squamous cell carcinoma of the head and neck: a randomized controlled trial. Radiother Oncol 104(3):343-348. doi:10.1016/j. radonc.2012.07.001

Gutin PH, Iwamoto FM, Beal K, Mohile NA, Karimi S, Hou BL, Lymberis S, Yamada Y, Chang J, Abrey LE (2009) Safety and efficacy of bevacizumab with hypofractionated stereotactic irradiation for recurrent malignant gliomas. Int J Radiat Oncol Biol Phys 75(1):156-163. doi:10.1016/j.ijrobp.2008.10.043
Hall EJ (2009) Is there a place for quantitative risk assessment? J Radiol Prot 29(2A):A171-A184

Halyard MY, Pisansky TM, Dueck AC, Suman V, Pierce L, Solin L, Marks L, Davidson N, Martino S, Kaufman P, Kutteh L, Dakhil SR, Perez EA (2009) Radiotherapy and adjuvant trastuzumab in operable breast cancer: tolerability and adverse event data from the NCCTG Phase III Trial N9831. J Clin Oncol 27(16): 2638-2644. doi:10.1200/JCO.2008.17.9549

Hanahan D, Weinberg RA (2000) The hallmarks of cancer. Cell 100(1):57-70. doi:10.1016/s0092-8674(00)81683-9

Hanahan D, Weinberg RA (2011) Hallmarks of cancer: the next generation. Cell 144(5):646-674. doi:10.1016/j.cell.2011.02.013

Hande KR (1998) Etoposide: four decades of development of a topoisomerase II inhibitor. Eur J Cancer 34(10):1514-1521

Harris PS, Venkataraman S, Alimova I, Birks DK, Donson AM, Knipstein J, Dubuc A, Taylor MD, Handler MH, Foreman NK, Vibhakar R (2012) Polo-like kinase 1 (PLK1) inhibition suppresses cell growth and enhances radiation sensitivity in medulloblastoma cells. BMC Cancer 12:80. doi:10.1186/14712407-12-80

Haupt S, Berger M, Goldberg Z, Haupt Y (2003) Apoptosis-the p53 network. J Cell Sci 116(Pt 20):4077-4085. doi:10.1242/jcs. 00739

Hegi ME, Diserens AC, Gorlia T, Hamou MF, de Tribolet N, Weller M, Kros JM, Hainfellner JA, Mason W, Mariani L, Bromberg JE, Hau P, Mirimanoff RO, Cairncross JG, Janzer RC, Stupp R (2005) MGMT gene silencing and benefit from temozolomide in glioblastoma. N Engl J Med 352(10):997-1003

Heinzelmann F, Jendrossek V, Lauber K, Nowak K, Eldh T, Boras R, Handrick R, Henkel M, Martin C, Uhlig S, Kohler D, Eltzschig HK, Wehrmann M, Budach W, Belka C (2006) Irradiationinduced pneumonitis mediated by the CD95/CD95-ligand system. J Natl Cancer Inst 98(17):1248-1251

Heldin C-H, Landström M, Moustakas A (2009) Mechanism of TGF$\beta$ signaling to growth arrest, apoptosis, and epithelial-mesenchymal transition. Curr Opin Cell Biol 21(2):166-176. doi:10. 1016/j.ceb.2009.01.021

Henke G, Meier V, Lindner LH, Eibl H, Bamberg M, Belka C, Budach W, Jendrossek V (2012) Effects of ionizing radiation in combination with Erufosine on T98G glioblastoma xenograft tumours: a study in NMRI nu/nu mice. Radiat Oncol 7(1):172. doi:10.1186/1748-717X-7-172

Hey J, Setz J, Gerlach R, Janich M, Hildebrandt G, Vordermark D, Gernhardt CR, Kuhnt T (2011) Parotid gland-recovery after radiotherapy in the head and neck region-36 months follow-up of a prospective clinical study. Radiat Oncol 6:125. doi:10.1186/ 1748-717X-6-125

Hickson I, Zhao Y, Richardson CJ, Green SJ, Martin NM, Orr AI, Reaper PM, Jackson SP, Curtin NJ, Smith GC (2004) Identification and characterization of a novel and specific inhibitor of the ataxia-telangiectasia mutated kinase ATM. Cancer Res 64(24):9152-9159

Hilgard P, Klenner T, Stekar J, Nossner G, Kutscher B, Engel J (1997) D-21266, a new heterocyclic alkylphospholipid with antitumour activity. Eur J Cancer 33(3):442-446

Hurley PJ, Bunz F (2007) ATM and ATR: components of an Integrated Circuit. Cell Cycle 6(4):414-417

Ihloff AS, Petersen C, Hoffmann M, Knecht R, Tribius S (2010) Human papilloma virus in locally advanced stage III/IV squamous cell cancer of the oropharynx and impact on choice of therapy. Oral Oncol 46(10):705-711. doi:10.1016/j. oraloncology.2010.07.006

Ikushima H, Miyazono K (2010) TGF $\beta$ signalling: a complex web in cancer progression. Nat Rev Cancer 10(6):415-424

Isomura M, Oya N, Tachiiri S, Kaneyasu Y, Nishimura Y, Akimoto T, Hareyama M, Sugita T, Mitsuhashi N, Yamashita T, Aoki M, 
Sai H, Hirokawa Y, Sakata K, Karasawa K, Tomida A, Tsuruo T, Miki Y, Noda T, Hiraoka M (2008) IL12RB2 and ABCA1 genes are associated with susceptibility to radiation dermatitis. Clin Cancer Res 14(20):6683-6689

Iyer R, Thames HD, Tealer JR, Mason KA, Evans SC (2004) Effect of reduced EGFR function on the radiosensitivity and proliferative capacity of mouse jejunal crypt clonogens. Radiother Oncol 72(3):283-289. doi:10.1016/j.radonc.2004.07.012

Jackson SP, Bartek J (2009) The DNA-damage response in human biology and disease. Nature 461(7267):1071-1078

Jacobs BL, Zhang Y, Hollenbeck BK (2012) Radiation therapy modalities for prostate cancer. JAMA 308 (5):450; author reply $451-452$

Jensen AD, Nikoghosyan AV, Ecker S, Ellerbrock M, Debus J, Herfarth KK, Munter MW (2011a) Raster-scanned carbon ion therapy for malignant salivary gland tumors: acute toxicity and initial treatment response. Radiat Oncol 6:149. doi:10.1186/ 1748-717X-6-149

Jensen AD, Nikoghosyan AV, Windemuth-Kieselbach C, Debus J, Munter MW (2011b) Treatment of malignant sinonasal tumours with intensity-modulated radiotherapy (IMRT) and carbon ion boost (C12). BMC Cancer 11:190. doi:1471-2407-11-190

Jiang X, Li T, Liu Y, Zhou L, Xu Y, Zhou X, Gong Y (2011) Planning analysis for locally advanced lung cancer: dosimetric and efficiency comparisons between intensity-modulated radiotherapy (IMRT), single-arc/partial-arc volumetric modulated arc therapy (SA/PA-VMAT). Radiat Oncol 6:140. doi:10.1186/ 1748-717X-6-140

Johnston CJ, Piedboeuf B, Rubin P, Williams JP, Baggs R, Finkelstein JN (1996) Early and persistent alterations in the expression of interleukin-1 alpha, interleukin-1 beta and tumor necrosis factor alpha mRNA levels in fibrosis-resistant and sensitive mice after thoracic irradiation. Radiat Res 145(6):762-767

Jordan CT, Guzman ML, Noble M (2006) Cancer stem cells. N Engl J Med 355(12):1253-1261. doi:10.1056/NEJMra061808

Jung H, Beck-Bornholdt HP, Svoboda V, Alberti W, Herrmann T (2001) Quantification of late complications after radiation therapy. Radiother Oncol 61(3):233-246

Kabakov AE, Makarova YM, Malyutina YV (2008) Radiosensitization of human vascular endothelial cells through Hsp90 inhibition with 17-N-allilamino-17-demethoxygeldanamycin. Int $\mathrm{J}$ Radiat Oncol Biol Phys 71(3):858-865

Kagan AR, Schulz RJ (2010) Proton-beam therapy for prostate cancer. Cancer J 16(5):405-409. doi:10.1097/PPO.0b013e $3181 \mathrm{f} 8 \mathrm{c} 25 \mathrm{~d}$

Karapetis CS, Khambata-Ford S, Jonker DJ, O'Callaghan CJ, Tu D, Tebbutt NC, Simes RJ, Chalchal H, Shapiro JD, Robitaille S, Price TJ, Shepherd L, Au HJ, Langer C, Moore MJ, Zalcberg JR (2008) K-ras mutations and benefit from cetuximab in advanced colorectal cancer. N Engl J Med 359(17):1757-1765. doi:10. 1056/NEJMoa0804385

Kasibhatla S, Tseng B (2003) Why target apoptosis in cancer treatment? Mol Cancer Ther 2(6):573-580

Kaufman HL, Disis ML (2004) Immune system versus tumor: shifting the balance in favor of DCs and effective immunity. J Clin Invest 113(5):664-667. doi:10.1172/JCI21148

Kaye SB, Lubinski J, Matulonis U, Ang JE, Gourley C, Karlan BY, Amnon A, Bell-McGuinn KM, Chen LM, Friedlander M, Safra T, Vergote I, Wickens M, Lowe ES, Carmichael J, Kaufman B (2012) Phase II, open-label, randomized, multicenter study comparing the efficacy and safety of olaparib, a poly (ADPribose) polymerase inhibitor, and pegylated liposomal doxorubicin in patients with BRCA1 or BRCA2 mutations and recurrent ovarian cancer. J Clin Oncol 30(4):372-379. doi:10.1200/JCO. 2011.36.9215
Kelly PJ, Dinkin MJ, Drappatz J, O’Regan KN, Weiss SE (2011) Unexpected late radiation neurotoxicity following bevacizumab use: a case series. J Neurooncol 102(3):485-490. doi:10.1007/ s11060-010-0336-0

Kim JH, Kim SH, Kolozsvary A, Khil MS (1992) Potentiation of radiation response in human carcinoma cells in vitro and murine fibrosarcoma in vivo by topotecan, an inhibitor of DNA topoisomerase I. Int $\mathbf{J}$ Radiat Oncol Biol Phys 22(3):515-518

Kobe C, Dietlein M, Fuchs M (2010) Interpretation and validation of interim positron emission tomography in Hodgkin lymphoma. Leuk Lymphoma 51(3):552-553. doi:10.3109/104281909 03585468

Koutcher LD, Wolden S, Lee N (2009) Severe radiation dermatitis in patients with locally advanced head and neck cancer treated with concurrent radiation and cetuximab. Am J Clin Oncol 32(5):472-476. doi:10.1097/COC.0b013e318193125c

Kraft SD, Richter C, Zeil K, Baumann M, Beyreuther E, Bock S, Bussmann M, Cowan TE, Dammene Y, Enghardt W, Helbig U, Karsch L, Kluge T, Laschinsky L, Lessmann E, Metzkes J, Naumburger D, Sauerbrey R, Schürer M, Sobiella M, Woithe J, Schramm U, Pawelke J (2010) Dose-dependent biological damage of tumour cells by laser-accelerated proton beams. New J Phys 12(8):085003

Krtolica A, Parrinello S, Lockett S, Desprez PY, Campisi J (2001) Senescent fibroblasts promote epithelial cell growth and tumorigenesis: a link between cancer and aging. Proc Natl Acad Sci USA 98(21):12072-12077. doi:10.1073/pnas.211053698

Kuilman T, Peeper DS (2009) Senescence-messaging secretome: SMS-ing cellular stress. Nat Rev Cancer 9(2):81-94. doi:10. 1038/nrc2560

Lai A, Filka E, McGibbon B, Nghiemphu PL, Graham C, Yong WH, Mischel P, Liau LM, Bergsneider M, Pope W, Selch M, Cloughesy T (2008) Phase II pilot study of bevacizumab in combination with temozolomide and regional radiation therapy for up-front treatment of patients with newly diagnosed glioblastoma multiforme: interim analysis of safety and tolerability. Int J Radiat Oncol Biol Phys 71(5):1372-1380. doi:10. 1016/j.ijrobp.2007.11.068

Lammering G, Hewit TH, Valerie K, Contessa JN, Amorino GP, Dent P, Schmidt-Ullrich RK (2003) EGFRvIII-mediated radioresistance through a strong cytoprotective response. Oncogene 22(36):5545-5553. doi:10.1038/sj.onc. 1206788

Lammering G, Valerie K, Lin PS, Hewit TH, Schmidt-Ullrich RK (2004) Radiation-induced activation of a common variant of EGFR confers enhanced radioresistance. Radiother Oncol 72(3):267-273. doi:10.1016/j.radonc.2004.07.004

Lauber K, Ernst A, Orth M, Herrmann M, Belka C (2012) Dying cell clearance and its impact on the outcome of tumor radiotherapy. Front Oncol 2:116. doi:10.3389/fonc.2012.00116

Lee Y, Auh SL, Wang Y, Burnette B, Meng Y, Beckett M, Sharma R, Chin R, Tu T, Weichselbaum RR, Fu YX (2009) Therapeutic effects of ablative radiation on local tumor require CD8+ T cells: changing strategies for cancer treatment. Blood 114(3):589-595. doi:10.1182/blood-2009-02-206870

Lee JW, Zoumalan RA, Valenzuela CD, Nguyen PD, Tutela JP, Roman BR, Warren SM, Saadeh PB (2010) Regulators and mediators of radiation-induced fibrosis: gene expression profiles and a rationale for Smad3 inhibition. Otolaryngol Head Neck Surg 143(4):525-530. doi:10.1016/j.otohns.2010.06.912

Li M, Jendrossek V, Belka C (2007) The role of PDGF in radiation oncology. Radiat Oncol 2:5

Li M, Abdollahi A, Grone HJ, Lipson KE, Belka C, Huber PE (2009) Late treatment with imatinib mesylate ameliorates radiationinduced lung fibrosis in a mouse model. Radiat Oncol 4:66. doi:10.1186/1748-717X-4-66 
Liao Z, Lin SH, Cox JD (2011) Status of particle therapy for lung cancer. Acta Oncol 50(6):745-756. doi:10.3109/0284186X. 2011.590148

Lindroos PM, Coin PG, Osornio-Vargas AR, Bonner JC (1995) Interleukin 1 beta (IL-1 beta) and the IL-1 beta-alpha 2-macroglobulin complex upregulate the platelet-derived growth factor alpha-receptor on rat pulmonary fibroblasts. Am J Respir Cell Mol Biol 13(4):455-465

Lordick F, Geinitz H, Theisen J, Sendler A, Sarbia M (2006) Increased risk of ischemic bowel complications during treatment with bevacizumab after pelvic irradiation: report of three cases. Int J Radiat Oncol Biol Phys 64(5):1295-1298

Lugade AA, Moran JP, Gerber SA, Rose RC, Frelinger JG, Lord EM (2005) Local radiation therapy of B16 melanoma tumors increases the generation of tumor antigen-specific effector cells that traffic to the tumor. J Immunol 174(12):7516-7523

Lugade AA, Sorensen EW, Gerber SA, Moran JP, Frelinger JG, Lord EM (2008) Radiation-induced IFN-gamma production within the tumor microenvironment influences antitumor immunity. J Immunol 180(5):3132-3139

Machida H, Nakajima S, Shikano N, Nishio J, Okada S, Asayama M, Shirai M, Kubota N (2005) Heat shock protein 90 inhibitor 17-allylamino-17-demethoxygeldanamycin potentiates the radiation response of tumor cells grown as monolayer cultures and spheroids by inducing apoptosis. Cancer Sci 96(12):911-917

Mantel F, Frey B, Haslinger S, Schildkopf P, Sieber R, Ott O, Lödermann B, Rödel F, Sauer R, Fietkau R, Gaipl U (2010) Combination of ionising irradiation and hyperthermia activates programmed apoptotic and necrotic cell death pathways in human colorectal carcinoma cells. Strahlenther Onkol 186(11):587-599. doi:10.1007/s00066-010-2154-x

Marini P, Budach W, Niyazi M, Junginger D, Stickl S, Jendrossek V, Belka C (2009a) Combination of the pro-apoptotic TRAILreceptor antibody mapatumumab with ionizing radiation strongly increases long-term tumor control under ambient and hypoxic conditions. Int J Radiat Oncol Biol Phys 75(1):198-202

Marini P, Junginger D, Stickl S, Budach W, Niyazi M, Belka C (2009b) Combined treatment with lexatumumab and irradiation leads to strongly increased long term tumour control under normoxic and hypoxic conditions. Radiat Oncol 4:49. doi:10. 1186/1748-717X-4-49

Martin S, Sydenham M, Haviland J, A'Hern R, Owen R, Bliss J, Yarnold J (2010) Test of association between variant tgbeta1 alleles and late adverse effects of breast radiotherapy. Radiother Oncol 97(1):15-18

Martinez I, Wang J, Hobson KF, Ferris RL, Khan SA (2007) Identification of differentially expressed genes in HPV-positive and HPV-negative oropharyngeal squamous cell carcinomas. Eur J Cancer 43(2):415-432

Massagué J, Blain SW, Lo RS (2000) TGF $\beta$ Signaling in Growth control, cancer, and heritable disorders. Cell 103(2):295-309. doi:10.1016/s0092-8674(00)00121-5

Matsumoto Y, Machida H, Kubota N (2005) Preferential sensitization of tumor cells to radiation by heat shock protein 90 inhibitor geldanamycin. J Radiat Res 46(2):215-221

Mattern MR, Hofmann GA, McCabe FL, Johnson RK (1991) Synergistic cell killing by ionizing radiation and topoisomerase I inhibitor topotecan (SK\&F 104864). Cancer Res 51(21):5813-5816

McBride WH (1995) Cytokine cascades in late normal tissue radiation responses. Int J Radiat Oncol Biol Phys 33(1):233-234

McDonald S, Rubin P, Phillips TL, Marks LB (1995) Injury to the lung from cancer therapy: clinical syndromes, measurable endpoints, and potential scoring systems. Int J Radiat Oncol Biol Phys 31(5):1187-1203
Meek DW (2009) Tumour suppression by p53: a role for the DNA damage response? Nat Rev Cancer 9(10):714-723

Mendenhall WM, Henderson RH, Hoppe BS, Nichols RC, Mendenhall NP (2012) Salvage of locally recurrent prostate cancer after definitive radiotherapy. Am J Clin Oncol. doi:10.1097/COC. 0b013e31824be3b4

Merchant TE (2009) Proton beam therapy in pediatric oncology. Cancer J 15(4):298-305. doi:10.1097/PPO.0b013e3181b6d4b7

Mertens AC, Yasui Y, Liu Y, Stovall M, Hutchinson R, Ginsberg J, Sklar C, Robison LL (2002) Pulmonary complications in survivors of childhood and adolescent cancer. A report from the Childhood Cancer Survivor Study. Cancer 95(11): 2431-2441. doi:10.1002/cncr.10978

Milanovi DA, Firat E, Grosu AL, Niedermann G (2013) Increased radiosensitivity and radiothermosensitivity of human pancreatic MIA PaCa-2 and U251 glioblastoma cell lines treated with the novel Hsp90 inhibitor NVP-HSP990. Radiat Oncol 8(1):42. doi: 10.1186/1748-717X-8-42

Milas L, Hunter NR, Mason KA, Kurdoglu B, Peters LJ (1994) Enhancement of tumor radioresponse of a murine mammary carcinoma by paclitaxel. Cancer Res 54(13):3506-3510

Milas L, Saito Y, Hunter N, Milross CG, Mason KA (1996) Therapeutic potential of paclitaxel-radiation treatment of a murine ovarian carcinoma. Radiother Oncol 40(2):163-170. doi:0167814096017781

Milas L, Mason K, Hunter N, Petersen S, Yamakawa M, Ang K, Mendelsohn J, Fan Z (2000) In vivo enhancement of tumor radioresponse by $\mathrm{C} 225$ antiepidermal growth factor receptor antibody. Clin Cancer Res 6(2):701-708

Milas L, Fan Z, Andratschke NH, Ang KK (2004) Epidermal growth factor receptor and tumor response to radiation: in vivo preclinical studies. Int J Radiat Oncol Biol Phys 58(3):966-971. doi:10. 1016/j.ijrobp.2003.08.035

Milross CG, Mason KA, Hunter NR, Terry NH, Patel N, Harada S, Jibu T, Seong J, Milas L (1997) Enhanced radioresponse of paclitaxel-sensitive and -resistant tumours in vivo. Eur J Cancer 33(8):1299-1308

Mitchell JB, Choudhuri R, Fabre K, Sowers AL, Citrin D, Zabludoff SD, Cook JA (2010) In vitro and in vivo radiation sensitization of human tumor cells by a novel checkpoint kinase inhibitor, AZD7762. Clin Cancer Res 16(7):2076-2084. doi:10.1158/ 1078-0432.CCR-09-3277

Miura K, K-i Sakata, Someya M, Matsumoto Y, Matsumoto H, Takahashi A, Hareyama M (2012) The combination of olaparib and camptothecin for effective radiosensitization. Radiat Oncol 7(1):62

Mok H, Crane CH, Palmer MB, Briere TM, Beddar S, Delclos ME, Krishnan S, Das P (2011) Intensity modulated radiation therapy (IMRT): differences in target volumes and improvement in clinically relevant doses to small bowel in rectal carcinoma. Radiat Oncol 6:63. doi:10.1186/1748-717X-6-63

Moretti L, Li B, Kim KW, Chen H, Lu B (2010) AT-101, a pan-Bcl-2 inhibitor, leads to radiosensitization of non-small cell lung cancer. J Thorac Oncol 5(5):680-687. doi:10.1097/JTO.0b013e $3181 \mathrm{~d} 6 \mathrm{e} 08 \mathrm{e}$

Moretti L, Niermann K, Schleicher S, Giacalone NJ, Varki V, Kim KW, Kopsombut P, Jung DK, Lu B (2011) MLN8054, a small molecule inhibitor of aurora kinase a, sensitizes androgenresistant prostate cancer to radiation. Int $\mathrm{J}$ Radiat Oncol Biol Phys 80(4):1189-1197. doi:10.1016/j.ijrobp.2011.01.060

Morgan MA, Parsels LA, Zhao L, Parsels JD, Davis MA, Hassan MC, Arumugarajah S, Hylander-Gans L, Morosini D, Simeone DM, Canman CE, Normolle DP, Zabludoff SD, Maybaum J, Lawrence TS (2010) Mechanism of radiosensitization by the Chk1/2 inhibitor AZD7762 involves abrogation of the G2 checkpoint and inhibition of homologous recombinational 
DNA repair. Cancer Res 70(12):4972-4981. doi:10.1158/00085472.CAN-09-3573

Movsas B, Raffin TA, Epstein AH, Link CJ Jr (1997) Pulmonary radiation injury. Chest 111(4):1061-1076

Munn DH, Mellor AL (2007) Indoleamine 2,3-dioxygenase and tumor-induced tolerance. J Clin Invest 117(5):1147-1154. doi:10.1172/JCI31178

Nardella C, Clohessy JG, Alimonti A, Pandolfi PP (2011) Pro-senescence therapy for cancer treatment. Nat Rev Cancer 11(7):503-511

Newhauser WD, Durante M (2011) Assessing the risk of second malignancies after modern radiotherapy. Nat Rev Cancer 11(6):438-448

Nieder C, Pawinski A, Dalhaug A, Andratschke N (2012) A review of clinical trials of cetuximab combined with radiotherapy for nonsmall cell lung cancer. Radiat Oncol 7:3. doi:10.1186/1748717X-7-3

Nikoghosyan AV, Karapanagiotou-Schenkel I, Munter MW, Jensen AD, Combs SE, Debus J (2010a) Randomised trial of proton vs. carbon ion radiation therapy in patients with chordoma of the skull base, clinical phase III study HIT-1-Study. BMC Cancer 10:607. doi:10.1186/1471-2407-10-607

Nikoghosyan AV, Rauch G, Munter MW, Jensen AD, Combs SE, Kieser M, Debus J (2010b) Randomised trial of proton vs. carbon ion radiation therapy in patients with low and intermediate grade chondrosarcoma of the skull base, clinical phase III study. BMC Cancer 10:606. doi:10.1186/1471-2407-10-606

Niyazi M, Marini P, Daniel PT, Humphreys R, Jendrossek V, Belka C (2009a) Efficacy of a triple treatment with irradiation, agonistic TRAIL receptor antibodies and EGFR blockade. Strahlenther Onkol 185(1):8-18. doi:10.1007/s00066-009-1856-4

Niyazi M, Marini P, Daniel PT, Humphreys R, Jendrossek V, Belka C (2009b) Efficacy of triple therapies including ionising radiation, agonistic TRAIL antibodies and cisplatin. Oncol Rep 21(6): $1455-1460$

Niyazi M, Bartenstein P, Belka C, Ganswindt U (2010) Choline PET based dose-painting in prostate cancer-modelling of dose effects. Radiat Oncol 5:23. doi:10.1186/1748-717X-5-23

Niyazi M, Geisler J, Siefert A, Schwarz SB, Ganswindt U, Garny S, Schnell O, Suchorska B, Kreth FW, Tonn JC, Bartenstein P, la Fougere C, Belka C (2011a) FET-PET for malignant glioma treatment planning. Radiother Oncol 99(1):44-48

Niyazi M, Maihoefer C, Krause M, Rodel C, Budach W, Belka C (2011b) Radiotherapy and "new" drugs-new side effects? Radiat Oncol 6:177. doi:10.1186/1748-717X-6-177

Niyazi M, Ganswindt U, Schwarz SB, Kreth FW, Tonn JC, Geisler J, la Fougere C, Ertl L, Linn J, Siefert A, Belka C (2012a) Irradiation and bevacizumab in high-grade glioma retreatment settings. Int J Radiat Oncol Biol Phys 82(1):67-76. doi:10.1016/ j.ijrobp.2010.09.002

Niyazi M, Schnell O, Suchorska B, Schwarz SB, Ganswindt U, Geisler J, Bartenstein P, Kreth FW, Tonn JC, Eigenbrod S, Belka C, la Fougere C (2012b) FET-PET assessed recurrence pattern after radio-chemotherapy in newly diagnosed patients with glioblastoma is influenced by MGMT methylation status. Radiother Oncol 104(1):78-82. doi:10.1016/j.radonc.2012.04.022

Njeh CF, Caroprese B, Desai P (2012) A simple quality assurance test tool for the visual verification of light and radiation field congruent using electronic portal images device and computed radiography. Radiat Oncol 7:49. doi:10.1186/1748-717X-7-49

Nystrom H (2010) The role of protons in modern and biologically guided radiotherapy. Acta Oncol 49(7):1124-1131. doi:10.3109/ 0284186X.2010.498436

Oldenhuis CN, Oosting SF, Gietema JA, de Vries EG (2008) Prognostic versus predictive value of biomarkers in oncology. Eur J Cancer 44(7):946-953. doi:10.1016/j.ejca.2008.03.006
O’Leary J, Muggia FM (1998) Camptothecins: a review of their development and schedules of administration. Eur $\mathrm{J}$ Cancer 34(10):1500-1508

Pallotta S, Marrazzo L, Ceroti M, Silli P, Bucciolini M (2012) A phantom evaluation of Sentinel $\left({ }^{\mathrm{TM}}\right)$, a commercial laser/camera surface imaging system for patient setup verification in radiotherapy. Med Phys 39(2):706-712. doi:10.1118/1.3675973

Pardali K, Moustakas A (2007) Actions of TGF- $\beta$ as tumor suppressor and pro-metastatic factor in human cancer. Biochimica et Biophysica Acta (BBA) 1775(1):21-62. doi:10.1016/j.bbcan. 2006.06.004

Pergolizzi S, Santacaterina A, Adamo B, Franchina T, Denaro N, Ferraro P, Ricciardi GR, Settineri N, Adamo V (2011) Induction chemotherapy with paclitaxel and cisplatin to concurrent radiotherapy and weekly paclitaxel in the treatment of loco-regionally advanced, stage IV (M0), head and neck squamous cell carcinoma. Mature results of a prospective study. Radiat Oncol 6:162. doi:10.1186/1748-717X-6-162

Peter C, Wesselborg S, Herrmann M, Lauber K (2010) Dangerous attraction: phagocyte recruitment and danger signals of apoptotic and necrotic cells. Apoptosis 15(9):1007-1028. doi:10.1007/ s10495-010-0472-1

Peters LJ, Withers HR, Thames HD Jr, Fletcher GH (1982) Tumor radioresistance in clinical radiotherapy. Int $\mathrm{J}$ Radiat Oncol Biol Phys 8(1):101-108

Peters NA, Richel DJ, Verhoeff JJ, Stalpers LJ (2008) Bowel perforation after radiotherapy in a patient receiving sorafenib. J Clin Oncol 26(14):2405-2406. doi:10.1200/JCO.2007.15. 8451

Phillips TM, McBride WH, Pajonk F (2006) The response of CD24-/ low/CD44+ breast cancer-initiating cells to radiation. J Natl Cancer Inst 98(24):1777-1785. doi:10.1093/jnci/djj495

Pignon JP, le Maitre A, Maillard E, Bourhis J (2009) Meta-analysis of chemotherapy in head and neck cancer (MACH-NC): an update on 93 randomised trials and 17,346 patients. Radiother Oncol 92(1):4-14. doi:10.1016/j.radonc.2009.04.014

Pinkawa M, Eble MJ, Mottaghy FM (2011) PET and PET/CT in radiation treatment planning for prostate cancer. Expert Rev Anticancer Ther 11(7):1033-1039. doi:10.1586/era.11.51

Pires IM, Olcina MM, Anbalagan S, Pollard JR, Reaper PM, Charlton PA, McKenna WG, Hammond EM (2012) Targeting radiationresistant hypoxic tumour cells through ATR inhibition. Br J Cancer 107(2):291-299. doi:10.1038/bjc.2012.265

Plathow C, Li M, Gong P, Zieher H, Kiessling F, Peschke P, Kauczor HU, Abdollahi A, Huber PE (2004) Computed tomography monitoring of radiation-induced lung fibrosis in mice. Invest Radiol 39(10):600-609

Pohlers D, Brenmoehl J, Loffler I, Muller CK, Leipner C, SchultzeMosgau S, Stallmach A, Kinne RW, Wolf G (2009) TGF-beta and fibrosis in different organs-molecular pathway imprints. Biochim Biophys Acta 1792(8):746-756

Pommier Y (2013) Drugging topoisomerases: lessons and challenges. ACS Chem Biol 8(1):82-95. doi:10.1021/cb300648v

Pottgen C, Levegrun S, Theegarten D, Marnitz S, Grehl S, Pink R, Eberhardt W, Stamatis G, Gauler T, Antoch G, Bockisch A, Stuschke M (2006) Value of 18F-fluoro-2-deoxy-D-glucosepositron emission tomography/computed tomography in nonsmall-cell lung cancer for prediction of pathologic response and times to relapse after neoadjuvant chemoradiotherapy. Clin Cancer Res 12(1):97-106. doi:12/1/97

Prestwich RJ, Kancherla K, Oksuz DC, Williamson D, Dyker KE, Coyle C, Sen M (2010) A single centre experience with sequential and concomitant chemoradiotherapy in locally advanced stage IV tonsillar cancer. Radiat Oncol 5:121. doi:10.1186/1748-717X-5-121 
Prevo R, Fokas E, Reaper PM, Charlton PA, Pollard JR, McKenna WG, Muschel RJ, Brunner TB (2012) The novel ATR inhibitor VE-821 increases sensitivity of pancreatic cancer cells to radiation and chemotherapy. Cancer Biol Ther 13(11):1072-1081. doi:10.4161/cbt.21093

Puthawala K, Hadjiangelis N, Jacoby SC, Bayongan E, Zhao Z, Yang Z, Devitt ML, Horan GS, Weinreb PH, Lukashev ME, Violette SM, Grant KS, Colarossi C, Formenti SC, Munger JS (2008) Inhibition of integrin alpha(v)beta6, an activator of latent transforming growth factor-beta, prevents radiation-induced lung fibrosis. Am J Respir Crit Care Med 177(1):82-90

Qian LW, Mizumoto K, Urashima T, Nagai E, Maehara N, Sato N, Nakajima M, Tanaka M (2002) Radiation-induced increase in invasive potential of human pancreatic cancer cells and its blockade by a matrix metalloproteinase inhibitor, CGS27023. Clin Cancer Res 8(4):1223-1227

Quarmby S, Fakhoury H, Levine E, Barber J, Wylie J, Hajeer AH, West C, Stewart A, Magee B, Kumar S (2003) Association of transforming growth factor beta-1 single nucleotide polymorphisms with radiation-induced damage to normal tissues in breast cancer patients. Int J Radiat Biol 79(2):137-143

Quon H, Abdulkarim B (2008) Adjuvant treatment of anaplastic oligodendrogliomas and oligoastrocytomas. Cochrane Database Syst Rev 16(2):CD007104. doi:10.1002/14651858.CD007104

Raabe A, Derda K, Reuther S, Szymczak S, Borgmann K, Hoeller U, Ziegler A, Petersen C, Dikomey E (2012) Association of single nucleotide polymorphisms in the genes ATM, GSTP1, SOD2, TGFB1, XPD and XRCC1 with risk of severe erythema after breast conserving radiotherapy. Radiat Oncol 7:65. doi:10.1186/ 1748-717X-7-65

Rabbani ZN, Anscher MS, Zhang X, Chen L, Samulski TV, Li C-Y, Vujaskovic Z (2003) Soluble TGF $\beta$ TYPE II receptor gene therapy ameliorates acute radiation-induced pulmonary injury in rats. Int J Radiat Oncol Biol Phys 57(2):563-572. doi:10.1016/ s0360-3016(03)00639-4

Ramaekers BLT, Pijls-Johannesma M, Joore MA, van den Ende P, Langendijk JA, Lambin P, Kessels AGH, Grutters JPC (2011) Systematic review and meta-analysis of radiotherapy in various head and neck cancers: comparing photons, carbon-ions and protons. Cancer Treat Rev 37(3):185-201. doi:10.1016/j.ctrv.2010.08.004

Reits EA, Hodge JW, Herberts CA, Groothuis TA, Chakraborty M, Wansley EK, Camphausen K, Luiten RM, de Ru AH, Neijssen J, Griekspoor A, Mesman E, Verreck FA, Spits H, Schlom J, van Veelen P, Neefjes JJ (2006) Radiation modulates the peptide repertoire, enhances MHC class I expression, and induces successful antitumor immunotherapy. J Exp Med 203(5): $1259-1271$

Reya T, Morrison SJ, Clarke MF, Weissman IL (2001) Stem cells, cancer, and cancer stem cells. Nature 414(6859):105-111

Rieckmann T, Tribius S, Grob TJ, Meyer F, Busch CJ, Petersen C, Dikomey E, Kriegs M (2013) HNSCC cell lines positive for HPV and p16 possess higher cellular radiosensitivity due to an impaired DSB repair capacity. Radiother Oncol 107(2):242-246. doi:10.1016/j.radonc.2013.03.013

Rigaud O, Fortunel NO, Vaigot P, Cadio E, Martin MT, Lundh O, Faure J, Rechatin C, Malka V, Gauduel YA (2010) Exploring ultrashort high-energy electron-induced damage in human carcinoma cells. Cell Death Dis 1:e73

Ringborg U, Bergqvist D, Brorsson B, Cavallin-Stahl E, Ceberg J, Einhorn N, Frodin JE, Jarhult J, Lamnevik G, Lindholm C, Littbrand B, Norlund A, Nylen U, Rosen M, Svensson H, Moller TR (2003) The Swedish Council on Technology Assessment in Health Care (SBU) systematic overview of radiotherapy for cancer including a prospective survey of radiotherapy practice in Sweden 2001-summary and conclusions. Acta Oncol 42(5-6):357-365
Rosen II, Fischer TA, Antolak JA, Starkschall G, Travis EL, Tucker SL, Hogstrom KR, Cox JD, Komaki R (2001) Correlation between lung fibrosis and radiation therapy dose after concurrent radiation therapy and chemotherapy for limited small cell lung cancer. Radiology 221(3):614-622

Rosenzweig KE, Mychalczak B, Fuks Z, Hanley J, Burman C, Ling CC, Armstrong J, Ginsberg R, Kris MG, Raben A, Leibel S (2000) Final report of the 70.2-Gy and 75.6-Gy dose levels of a phase I dose escalation study using three-dimensional conformal radiotherapy in the treatment of inoperable non-small cell lung cancer. Cancer J 6(2):82-87

Rubel A, Handrick R, Lindner LH, Steiger M, Eibl H, Budach W, Belka C, Jendrossek V (2006) The membrane targeted apoptosis modulators erucylphosphocholine and erucylphosphohomocholine increase the radiation response of human glioblastoma cell lines in vitro. Radiat Oncol 1:6. doi:10.1186/1748-717X-1-6

Rudin CM, Hann CL, Garon EB, Ribeiro de Oliveira M, Bonomi PD, Camidge DR, Chu Q, Giaccone G, Khaira D, Ramalingam SS, Ranson MR, Dive C, McKeegan EM, Chyla BJ, Dowell BL, Chakravartty A, Nolan CE, Rudersdorf N, Busman TA, Mabry MH, Krivoshik AP, Humerickhouse RA, Shapiro GI, Gandhi L (2012) Phase II study of single-agent navitoclax (ABT-263) and biomarker correlates in patients with relapsed small cell lung cancer. Clin Cancer Res 18(11):3163-3169. doi:1078-0432. CCR-11-3090

Rudner CBPMRJWHFAL-WMBWBJ (2001) Radiation sensitivity and apoptosis in human lymphoma cells. Int $\mathrm{J}$ Radiat Biol 77(1):1-11. doi:10.1080/095530001453069

Ruiter GA, Zerp SF, Bartelink H, van Blitterswijk WJ, Verheij M (1999) Alkyl-lysophospholipids activate the SAPK/JNK pathway and enhance radiation-induced apoptosis. Cancer Res 59(10):2457-2463

Russell JS, Burgan W, Oswald KA, Camphausen K, Tofilon PJ (2003) Enhanced cell killing induced by the combination of radiation and the heat shock protein 90 inhibitor 17-allylamino-17demethoxygeldanamycin: a multitarget approach to radiosensitization. Clin Cancer Res 9(10 Pt 1):3749-3755

Safwat A, Bentzen SM, Turesson I, Hendry JH (2002) Deterministic rather than stochastic factors explain most of the variation in the expression of skin telangiectasia after radiotherapy. Int J Radiat Oncol Biol Phys 52(1):198-204

Samani AA, Yakar S, LeRoith D, Brodt P (2007) The role of the IGF system in cancer growth and metastasis: overview and recent insights. Endocr Rev 28(1):20-47

Schildkopf P, Frey B, Mantel F, Ott OJ, Weiss EM, Sieber R, Janko C, Sauer R, Fietkau R, Gaipl US (2010) Application of hyperthermia in addition to ionizing irradiation fosters necrotic cell death and HMGB1 release of colorectal tumor cells. Biochem Biophys Res Commun 391(1):1014-1020. doi:10. 1016/j.bbrc.2009.12.008

Schippers JM, Lomax AJ (2011) Emerging technologies in proton therapy. Acta Oncol 50(6):838-850. doi:10.3109/0284186X. 2011.582513

Schmid TE, Dollinger G, Hauptner A, Hable V, Greubel C, Auer S, Friedl AA, Molls M, Roper B (2009) No evidence for a different RBE between pulsed and continuous $20 \mathrm{MeV}$ protons. Radiat Res 172(5):567-574. doi:10.1667/RR1539.1

Schmid TE, Dollinger G, Hable V, Greubel C, Zlobinskaya O, Michalski D, Molls M, Roper B (2010) Relative biological effectiveness of pulsed and continuous $20 \mathrm{MeV}$ protons for micronucleus induction in 3D human reconstructed skin tissue. Radiother Oncol 95(1):66-72

Schreiber RD, Old LJ, Smyth MJ (2011) Cancer immunoediting: integrating immunity's roles in cancer suppression and promotion. Science 331(6024):1565-1570. doi:10.1126/science. 1203486 
Seger R, Krebs EG (1995) The MAPK signaling cascade. FASEB J 9(9):726-735

Sengupta S, Harris CC (2005) p53: traffic cop at the crossroads of DNA repair and recombination. Nat Rev Mol Cell Biol 6(1):44-55

Senra JM, Telfer BA, Cherry KE, McCrudden CM, Hirst DG, O'Connor MJ, Wedge SR, Stratford IJ (2011) Inhibition of PARP-1 by olaparib (AZD2281) increases the radiosensitivity of a lung tumor xenograft. Mol Cancer Ther 10(10):1949-1958. doi:10.1158/1535-7163.MCT-11-0278

Sheets NC, Goldin GH, Meyer AM, Wu Y, Chang Y, Sturmer T, Holmes JA, Reeve BB, Godley PA, Carpenter WR, Chen RC (2012) Intensity-modulated radiation therapy, proton therapy, or conformal radiation therapy and morbidity and disease control in localized prostate cancer. JAMA 307(15):1611-1620

Shelton JW, Waxweiler TV, Landry J, Gao H, Xu Y, Wang L, ElRayes B, Shu HK (2013) In Vitro and In Vivo Enhancement of Chemoradiation Using the Oral PARP Inhibitor ABT-888 in Colorectal Cancer Cells. Int $\mathrm{J}$ Radiat Oncol Biol Phys 86(3):469-476. doi:10.1016/j.ijrobp.2013.02.015

Sherr CJ, Roberts JM (1999) CDK inhibitors: positive and negative regulators of G1-phase progression. Genes Dev 13(12): $1501-1512$

Shi A, Zhu G, Wu H, Yu R, Li F, Xu B (2010) Analysis of clinical and dosimetric factors associated with severe acute radiation pneumonitis in patients with locally advanced non-small cell lung cancer treated with concurrent chemotherapy and intensitymodulated radiotherapy. Radiat Oncol 5:35. doi:10.1186/1748$717 \mathrm{X}-5-35$

Shiloh Y (2006) The ATM-mediated DNA-damage response: taking shape. Trends Biochem Sci 31(7):402-410. doi:10.1016/j.tibs. 2006.05.004

Shin S, Yoon H, Kim N, Lee K, Min B, Ahn J, Keum K, Koom W (2011) Upfront systemic chemotherapy and preoperative shortcourse radiotherapy with delayed surgery for locally advanced rectal cancer with distant metastases. Radiat Oncol 6(1):99

Silvano G, Lazzari G, Lovecchio M, Palazzo C (2008) Acute and fatal diarrhoea after erlotinib plus abdominal palliative hypofractionated radiotherapy in a metastatic non-small cell lung cancer patient: a case report. Lung Cancer 61(2):270-273. doi:10.1016/ j.lungcan.2008.03.004

Sinclair WK, Morton RA (1966) X-ray sensitivity during the cell generation cycle of cultured Chinese hamster cells. Radiat Res 29(3):450-474

Smith J, Mun Tho L, Xu N, A. Gillespie D (2010) Chapter 3 - The ATM-Chk2 and ATR-Chk1 Pathways in DNA Damage Signaling and Cancer. In: George FVW, George K (eds) Advances in Cancer Research, vol Volume 108. Academic Press, pp 73-112. doi:10.1016/b978-0-12-380888-2.00003-0

Snow AN, Laudadio J (2010) Human papillomavirus detection in head and neck squamous cell carcinomas. Adv Anat Pathol 17(6):394-403. doi:10.1097/PAP.0b013e3181f895c1

Song SY, Kim JH, Ryu JS, Lee GH, Kim SB, Park SI, Song HY, Cho KJ, Ahn SD, Lee SW, Shin SS, Choi EK (2005) FDG-PET in the prediction of pathologic response after neoadjuvant chemoradiotherapy in locally advanced, resectable esophageal cancer. Int J Radiat Oncol Biol Phys 63(4):1053-1059

Spigel DR, Hainsworth JD, Yardley DA, Raefsky E, Patton J, Peacock N, Farley C, Burris HA 3rd, Greco FA (2010) Tracheoesophageal fistula formation in patients with lung cancer treated with chemoradiation and bevacizumab. J Clin Oncol 28(1):43-48. doi:10.1200/JCO.2009.24.7353

Srivastava M, Nambiar M, Sharma S, Karki SS, Goldsmith G, Hegde M, Kumar S, Pandey M, Singh RK, Ray P, Natarajan R, Kelkar M, De A, Choudhary B, Raghavan SC (2012) An inhibitor of nonhomologous end-joining abrogates double-strand break repair and impedes cancer progression. Cell 151(7):1474-1487. doi:10.1016/j.cell.2012.11.054

Stingl L, Stuhmer T, Chatterjee M, Jensen MR, Flentje M, Djuzenova CS (2010) Novel HSP90 inhibitors, NVP-AUY922 and NVPBEP800, radiosensitise tumour cells through cell-cycle impairment, increased DNA damage and repair protraction. $\mathrm{Br} \mathrm{J}$ Cancer 102(11):1578-1591

Stupp R, Hegi ME, Mason WP, van den Bent MJ, Taphoorn MJ, Janzer RC, Ludwin SK, Allgeier A, Fisher B, Belanger K, Hau P, Brandes AA, Gijtenbeek J, Marosi C, Vecht CJ, Mokhtari K, Wesseling P, Villa S, Eisenhauer E, Gorlia T, Weller M, Lacombe D, Cairncross JG, Mirimanoff RO (2009) Effects of radiotherapy with concomitant and adjuvant temozolomide versus radiotherapy alone on survival in glioblastoma in a randomised phase III study: 5-year analysis of the EORTCNCIC trial. Lancet Oncol 10(5):459-466. doi:10.1016/S14702045(09)70025-7

Taghian AG, Assaad SI, Niemierko A, Kuter I, Younger J, Schoenthaler R, Roche M, Powell SN (2001) Risk of pneumonitis in breast cancer patients treated with radiation therapy and combination chemotherapy with paclitaxel. J Natl Cancer Inst 93(23): 1806-1811

Tajima T (2010) Laser acceleration and its future. Proc Jpn Acad Ser B Phys Biol Sci 86(3):147-157

Takeda K, Takai Y, Narazaki K, Mitsuya M, Umezawa R, Kadoya N, Fujita Y, Sugawara T, Kubozono M, Shimizu E, Abe K, Shirata Y, Ishikawa Y, Yamamoto T, Kozumi M, Dobashi S, Matsushita H, Chida K, Ishidoya S, Arai Y, Jingu K, Yamada S (2012) Treatment outcome of high-dose image-guided intensity-modulated radiotherapy using intra-prostate fiducial markers for localized prostate cancer at a single institute in Japan. Radiat Oncol 7:105. doi:10.1186/1748-717X-7-105

Tao Y, Zhang P, Girdler F, Frascogna V, Castedo M, Bourhis J, Kroemer G, Deutsch E (2008) Enhancement of radiation response in p53-deficient cancer cells by the Aurora-B kinase inhibitor AZD1152. Oncogene 27(23):3244-3255

Tao Y, Leteur C, Calderaro J, Girdler F, Zhang P, Frascogna V, Varna M, Opolon P, Castedo M, Bourhis J, Kroemer G, Deutsch E (2009) The aurora B kinase inhibitor AZD1152 sensitizes cancer cells to fractionated irradiation and induces mitotic catastrophe. Cell Cycle 8(19):3172-3181. doi:9729

Tao Y, Bardet E, Rosine D, Rolland F, Bompas E, Daly-Schveitzer N, Lusinchi A, Bourhis J (2013) Phase I trial of oral etoposide in combination with radiotherapy in head and neck squamous cell carcinoma-GORTEC 2004-02. Radiat Oncol 8:40. doi:10.1186/ 1748-717X-8-40

Taylor RC, Cullen SP, Martin SJ (2008) Apoptosis: controlled demolition at the cellular level. Nat Rev Mol Cell Biol 9(3):231-241

Terasima T, Tolmach LJ (1963) X-ray sensitivity and DNA synthesis in synchronous populations of HeLa cells. Science 140(3566):490-492

Thiery JP, Acloque H, Huang RY, Nieto MA (2009) Epithelialmesenchymal transitions in development and disease. Cell 139(5):871-890. doi:10.1016/j.cell.2009.11.007

Thorwarth D, Geets X, Paiusco M (2010) Physical radiotherapy treatment planning based on functional PET/CT data. Radiother Oncol 96(3):317-324

Timmerman R, Paulus R, Galvin J, Michalski J, Straube W, Bradley J, Fakiris A, Bezjak A, Videtic G, Johnstone D, Fowler J, Gore E, Choy H (2010) Stereotactic body radiation therapy for inoperable early stage lung cancer. JAMA 303(11):1070-1076. doi:10.1001/jama.2010.261

Tishler RB, Geard CR, Hall EJ, Schiff PB (1992) Taxol sensitizes human astrocytoma cells to radiation. Cancer Res 52(12): $3495-3497$ 
Toulany M, Dittmann K, Kruger M, Baumann M, Rodemann HP (2005) Radioresistance of K-Ras mutated human tumor cells is mediated through EGFR-dependent activation of PI3 K-AKT pathway. Radiother Oncol 76(2):143-150

Turesson I, Nyman J, Holmberg E, Oden A (1996) Prognostic factors for acute and late skin reactions in radiotherapy patients. Int $\mathrm{J}$ Radiat Oncol Biol Phys 36(5):1065-1075

Tutt A, Robson M, Garber JE, Domchek SM, Audeh MW, Weitzel JN, Friedlander M, Arun B, Loman N, Schmutzler RK, Wardley A, Mitchell G, Earl H, Wickens M, Carmichael J (2010) Oral poly(ADP-ribose) polymerase inhibitor olaparib in patients with BRCA1 or BRCA2 mutations and advanced breast cancer: a proof-of-concept trial. Lancet 376(9737):235-244. doi:10.1016/ S0140-6736(10)60892-6

Unger C, Damenz W, Fleer EA, Kim DJ, Breiser A, Hilgard P, Engel J, Nagel G, Eibl H (1989) Hexadecylphosphocholine, a new ether lipid analogue. Studies on the antineoplastic activity in vitro and in vivo. Acta Oncol 28(2):213-217

Valastyan S, Weinberg RA (2011) Tumor metastasis: molecular insights and evolving paradigms. Cell 147(2):275-292. doi:10. 1016/j.cell.2011.09.024

van den Bent MJ, Carpentier AF, Brandes AA, Sanson M, Taphoorn MJ, Bernsen HJ, Frenay M, Tijssen CC, Grisold W, Sipos L, Haaxma-Reiche H, Kros JM, van Kouwenhoven MC, Vecht CJ, Allgeier A, Lacombe D, Gorlia T (2006) Adjuvant procarbazine, lomustine, and vincristine improves progression-free survival but not overall survival in newly diagnosed anaplastic oligodendrogliomas and oligoastrocytomas: a randomized European Organisation for Research and Treatment of Cancer phase III trial. J Clin Oncol 24(18):2715-2722. doi:24/18/2715

van Herk M (2004) Errors and margins in radiotherapy. Semin Radiat Oncol 14(1):52-64

Vandenabeele P, Galluzzi L, Vanden Berghe T, Kroemer G (2010) Molecular mechanisms of necroptosis: an ordered cellular explosion. Nat Rev Mol Cell Biol 11(10):700-714

Vees H, Steiner C, Dipasquale G, Chouiter A, Zilli T, Velazquez M, Namy S, Ratib O, Buchegger F, Miralbell R (2012) Target volume definition in high-risk prostate cancer patients using sentinel node SPECT/CT and 18 F-choline PET/CT. Radiat Oncol 7:134. doi:10.1186/1748-717X-7-134

Velenik V, Ocvirk J, Music M, Bracko M, Anderluh F, Oblak I, Edhemovic I, Brecelj E, Kropivnik M, Omejc M (2011) Neoadjuvant capecitabine, radiotherapy, and bevacizumab $(\mathrm{CRAB})$ in locally advanced rectal cancer: results of an openlabel phase II study. Radiat Oncol 6(1):105

Vink SR, Lagerwerf S, Mesman E, Schellens JH, Begg AC, van Blitterswijk WJ, Verheij M (2006) Radiosensitization of squamous cell carcinoma by the alkylphospholipid perifosine in cell culture and xenografts. Clin Cancer Res 12(5):1615-1622

Vink SR, van Blitterswijk WJ, Schellens JH, Verheij M (2007) Rationale and clinical application of alkylphospholipid analogues in combination with radiotherapy. Cancer Treat Rev 33(2):191-202

Vogelius IR, Westerly DC, Aznar MC, Cannon GM, Korreman SS, Mackie TR, Mehta MP, Bentzen SM (2011) Estimated radiation pneumonitis risk after photon versus proton therapy alone or combined with chemotherapy for lung cancer. Acta Oncol 50(6):772-776. doi:10.3109/0284186X.2011.582519

Vogler M, Dinsdale D, Dyer MJ, Cohen GM (2009) Bcl-2 inhibitors: small molecules with a big impact on cancer therapy. Cell Death Differ 16(3):360-367

Vorwerk H, Hess CF (2011) Guidelines for delineation of lymphatic clinical target volumes for high conformal radiotherapy: head and neck region. Radiat Oncol 6:97. doi:10.1186/1748-717X-697
Vredenburgh JJ, Desjardins A, Kirkpatrick JP, Reardon DA, Peters KB, Herndon JE 2nd, Marcello J, Bailey L, Threatt S, Sampson J, Friedman A, Friedman HS (2012) Addition of bevacizumab to standard radiation therapy and daily temozolomide is associated with minimal toxicity in newly diagnosed glioblastoma multiforme. Int J Radiat Oncol Biol Phys 82(1):58-66. doi:10.1016/j. ijrobp.2010.08.058

Wachsberger P, Burd R, Dicker AP (2003) Tumor response to ionizing radiation combined with antiangiogenesis or vascular targeting agents: exploring mechanisms of interaction. Clin Cancer Res 9(6):1957-1971

Wakatsuki M, Ohno T, Iwakawa M, Ishikawa H, Noda S, Ohta T, Kato S, Tsujii H, Imai $T$, Nakano $T$ (2008) p73 protein expression correlates with radiation-induced apoptosis in the lack of p53 response to radiation therapy for cervical cancer. Int J Radiat Oncol Biol Phys 70(4):1189-1194. doi:10.1016/j.ijrobp. 2007.08.033

Walsh L, Gillham C, Dunne M, Fraser I, Hollywood D, Armstrong J, Thirion P (2011) Toxicity of cetuximab versus cisplatin concurrent with radiotherapy in locally advanced head and neck squamous cell cancer (LAHNSCC). Radiother Oncol 98(1):38-41. doi:10.1016/j.radonc.2010.11.009

Walter F, la Fougere C, Belka C, Niyazi M (2012) Technical Issues of [(18)F]FET-PET Imaging for Radiation Therapy Planning in Malignant Glioma Patients-A Review. Front Oncol 2:130. doi:10.3389/fonc.2012.00130

Weber U, Kraft G (2009) Comparison of carbon ions versus protons. Cancer J 15(4):325-332. doi:10.1097/PPO.0b013e3181b01935

Weidner AM, van Lin EN, Dinter DJ, Rozema T, Schoenberg SO, Wenz F, Barentsz JO, Lohr F (2011) Ferumoxtran-10 MR lymphography for target definition and follow-up in a patient undergoing image-guided, dose-escalated radiotherapy of lymph nodes upon PSA relapse. Strahlenther Onkol 187(3):206-212. doi:10.1007/s00066-010-2195-1

Wernicke AG, Dicker AP, Whiton M, Ivanidze J, Hyslop T, Hammond EH, Perry A, Andrews DW, Kenyon L (2010) Assessment of Epidermal Growth Factor Receptor (EGFR) expression in human meningioma. Radiat Oncol 5:46. doi:10. 1186/1748-717X-5-46

Wesbuer S, Lanvers-Kaminsky C, Duran-Seuberth I, Bolling T, Schafer K-L, Braun Y, Willich N, Greve B (2010) Association of telomerase activity with radio- and chemosensitivity of neuroblastomas. Radiat Oncol 5(1):66

Wiezorek T, Brachwitz T, Georg D, Blank E, Fotina I, Habl G, Kretschmer M, Lutters G, Salz H, Schubert K, Wagner D, Wendt TG (2011) Rotational IMRT techniques compared to fixed gantry IMRT and tomotherapy: multi-institutional planning study for head-and-neck cases. Radiat Oncol 6:20. doi:10. 1186/1748-717X-6-20

Wild-Bode C, Weller M, Rimner A, Dichgans J, Wick W (2001) Sublethal irradiation promotes migration and invasiveness of glioma cells: implications for radiotherapy of human glioblastoma. Cancer Res 61(6):2744-2750

Willett CG, Boucher Y, di Tomaso E, Duda DG, Munn LL, Tong RT, Chung DC, Sahani DV, Kalva SP, Kozin SV, Mino M, Cohen KS, Scadden DT, Hartford AC, Fischman AJ, Clark JW, Ryan DP, Zhu AX, Blaszkowsky LS, Chen HX, Shellito PC, Lauwers GY, Jain RK (2004) Direct evidence that the VEGF-specific antibody bevacizumab has antivascular effects in human rectal cancer. Nat Med 10(2):145-147. doi:10.1038/nm988

Williams KJ, Telfer BA, Brave S, Kendrew J, Whittaker L, Stratford IJ, Wedge SR (2004) ZD6474, a potent inhibitor of vascular endothelial growth factor signaling, combined with radiotherapy: schedule-dependent enhancement of antitumor activity. Clin Cancer Res 10(24):8587-8593 
Woodward WA, Chen MS, Behbod F, Alfaro MP, Buchholz TA, Rosen JM (2007) WNT/ $\beta$-catenin mediates radiation resistance of mouse mammary progenitor cells. Proc Natl Acad Sci 104(2):618-623. doi:10.1073/pnas.0606599104

Wurschmidt F, Petersen C, Wahl A, Dahle J, Kretschmer M (2011) [18F]fluoroethylcholine-PET/CT imaging for radiation treatment planning of recurrent and primary prostate cancer with dose escalation to PET/CT-positive lymph nodes. Radiat Oncol 6:44. doi:10.1186/1748-717X-6-44

Wynn TA (2008) Cellular and molecular mechanisms of fibrosis. J Pathol 214(2):199-210. doi:10.1002/path.2277

Xavier S, Piek E, Fujii M, Javelaud D, Mauviel A, Flanders KC, Samuni AM, Felici A, Reiss M, Yarkoni S, Sowers A, Mitchell JB, Roberts AB, Russo A (2004) Amelioration of radiationinduced fibrosis. J Biol Chem 279(15):15167-15176. doi:10. 1074/jbc.M309798200

Xing L, Thorndyke B, Schreibmann E, Yang Y, Li TF, Kim GY, Luxton G, Koong A (2006) Overview of image-guided radiation therapy. Med Dosim 31(2):91-112

Xiong H, Liao Z, Liu Z, Xu T, Wang Q, Liu H, Komaki R, Gomez D, Wang LE, Wei Q (2012) ATM Polymorphisms predict severe radiation pneumonitis in patients with non-small cell lung cancer treated with definitive radiation therapy. Int J Radiat Oncol Biol Phys 85(4):1066-1073. doi:10.1016/j.ijrobp.2012.09.024

Yan H, Parsons DW, Jin G, McLendon R, Rasheed BA, Yuan W, Kos I, Batinic-Haberle I, Jones S, Riggins GJ, Friedman H, Friedman A, Reardon D, Herndon J, Kinzler KW, Velculescu VE, Vogelstein B, Bigner DD (2009) IDH1 and IDH2 mutations in gliomas. N Engl J Med 360(8):765-773. doi:10.1056/ NEJMoa0808710

Yang S, Wu J, Zuo Y, Tan L, Jia H, Yan H, Zhu X, Zeng M, Ma J, Huang W (2010) ZD6474, a small molecule tyrosine kinase inhibitor, potentiates the anti-tumor and anti-metastasis effects of radiation for human nasopharyngeal carcinoma. Curr Cancer Drug Targets 10(6):611-622

Yaromina A, Zips D (2010) Bio-IGRT-biological image-guided radiotherapy. Nuklearmedizin 49(Suppl 1):S50-S52

Yin H, Glass J (2011) The phenotypic radiation resistance of CD44+/ CD24(-or low) breast cancer cells is mediated through the enhanced activation of ATM signaling. PLoS ONE 6(9):e24080. doi:10.1371/journal.pone.0024080

Yogo A, Sato K, Nishikino M, Mori M, Teshima T, Numasaki H, Murakami M, Demizu Y, Akagi S, Nagayama S, Ogura K,
Sagisaka A, Orimo S, Nishiuchi M, Pirozhkov AS, Ikegami M, Tampo M, Sakaki H, Suzuki M, Daito I, Oishi Y, Sugiyama H, Kiriyama H, Okada H, Kanazawa S, Kondo S, Shimomura T, Nakai Y, Tanoue M, Sasao H, Wakai D, Bolton PR, Daido H (2009) Application of laser-accelerated protons to the demonstration of DNA double-strand breaks in human cancer cells. Appl Phys Lett 94(18):181502-181503

Youle RJ, Strasser A (2008) The BCL-2 protein family: opposing activities that mediate cell death. Nat Rev Mol Cell Biol 9(1):47-59

Young JC, Agashe VR, Siegers K, Hartl FU (2004) Pathways of chaperone-mediated protein folding in the cytosol. Nat Rev Mol Cell Biol 5(10):781-791. doi:10.1038/nrm1492

Zabludoff SD, Deng C, Grondine MR, Sheehy AM, Ashwell S, Caleb BL, Green S, Haye HR, Horn CL, Janetka JW, Liu D, Mouchet E, Ready S, Rosenthal JL, Queva C, Schwartz GK, Taylor KJ, Tse AN, Walker GE, White AM (2008) AZD7762, a novel checkpoint kinase inhibitor, drives checkpoint abrogation and potentiates DNA-targeted therapies. Mol Cancer Ther 7(9):2955-2966. doi:10.1158/1535-7163.MCT-08-0492

Zerp SF, Stoter R, Kuipers G, Yang D, Lippman ME, van Blitterswijk WJ, Bartelink H, Rooswinkel R, Lafleur V, Verheij M (2009) AT-101, a small molecule inhibitor of anti-apoptotic Bcl-2 family members, activates the SAPK/JNK pathway and enhances radiation-induced apoptosis. Radiat Oncol 4:47. doi:10.1186/ 1748-717X-4-47

Zhang K, Phan SH (1996) Cytokines and pulmonary fibrosis. Biol Signals 5(4):232-239

Zlobinskaya O, Dollinger G, Michalski D, Hable V, Greubel C, Du G, Multhoff G, Roper B, Molls M, Schmid TE (2012) Induction and repair of DNA double-strand breaks assessed by gamma-H2AX foci after irradiation with pulsed or continuous proton beams. Radiat Environ Biophys 51(1):23-32. doi:10.1007/s00411-0110398-1

Zschenker O, Raabe A, Boeckelmann IK, Borstelmann S, Szymczak S, Wellek S, Rades D, Hoeller U, Ziegler A, Dikomey E, Borgmann K (2010) Association of single nucleotide polymorphisms in ATM, GSTP1, SOD2, TGFB1, XPD and XRCC1 with clinical and cellular radiosensitivity. Radiother Oncol 97(1): 26-32 